\title{
Article \\ A Collagen Basketweave from the Giant Squid Mantle as a Robust Scaffold for Tissue Engineering
}

\author{
Anastasia Frolova ${ }^{1, *(1)}$, Nadezhda Aksenova ${ }^{2,3}$, Ivan Novikov ${ }^{4}$, Aitsana Maslakova ${ }^{5}$, Elvira Gafarova ${ }^{1}$, \\ Yuri Efremov ${ }^{1,2}$, Polina Bikmulina ${ }^{1}$, Vadim Elagin ${ }^{6}{ }^{\circ}$, Elena Istranova ${ }^{2}$, Alexandr Kurkov ${ }^{2}$, Anatoly Shekhter ${ }^{2}$, \\ Svetlana Kotova $\left.{ }^{2,3}{ }^{(}\right)$, Elena Zagaynova ${ }^{7}$ and Peter Timashev ${ }^{1,2,3,8} \mathbb{C}$
}

1 World-Class Research Center "Digital Biodesign and Personalized Healthcare", Sechenov First Moscow State Medical University (Sechenov University), 8-2 Trubetskaya Street, 119991 Moscow, Russia; gafarova_e_r@staff.sechenov.ru (E.G.); efremov_yu_m@staff.sechenov.ru (Y.E.); bikmulina_p_yu@staff.sechenov.ru (P.B.); timashev_p_s@staff.sechenov.ru (P.T.)

2 Institute for Regenerative Medicine, Sechenov First Moscow State Medical University (Sechenov University), 8-2 Trubetskaya Street, 119991 Moscow, Russia; aksenova_n_a@staff.sechenov.ru (N.A.); istranova_e_v@staff.sechenov.ru (E.I.); kurkov_a_v@staff.sechenov.ru (A.K.); shekhter_a_b@staff.sechenov.ru (A.S.); kotova_s_1@staff.sechenov.ru (S.K.)

3 N.N. Semenov Federal Research Center for Chemical Physics, RAS, 4 Kosygin Street, 119991 Moscow, Russia

4 Research Institute of Eye Diseases, 11 Rossolimo Street, 119021 Moscow, Russia; i.novikov@niigb.ru

5 Faculty of Biology, Department of Human and Animal Physiology, M.V. Lomonosov Moscow State University, 1-12 Leninskie Gory, 119991 Moscow, Russia; aitsana.dokrunova@gmail.com

6 Institute of Experimental Oncology and Biomedical Technologies, Privolzhsky Research Medical University, Minin and Pozharsky Square 10/1, 603950 Nizhny Novgorod, Russia; elagin.vadim@gmail.com

check for updates

Citation: Frolova, A.; Aksenova, N.; Novikov, I.; Maslakova, A.; Gafarova, E.; Efremov, Y.; Bikmulina, P.; Elagin, V.; Istranova, E.; Kurkov, A.; et al. A Collagen Basketweave from the Giant Squid Mantle as a Robust Scaffold for Tissue Engineering. Mar. Drugs 2021, 19, 679. https://doi.org/10.3390/ md19120679

Academic Editor: Sik Yoon

Received: 17 November 2021

Accepted: 20 November 2021

Published: 29 November 2021

Publisher's Note: MDPI stays neutral with regard to jurisdictional claims in published maps and institutional affiliations.

Copyright: (c) 2021 by the authors. Licensee MDPI, Basel, Switzerland. This article is an open access article distributed under the terms and conditions of the Creative Commons Attribution (CC BY) license (https:// creativecommons.org/licenses/by/ $4.0 /)$.
7 Institute of Experimental Oncology and Biomedical Technologies, National Research Lobachevsky State University of Nizhny Novgorod, Prospekt Gagarina (Gagarin Avenue) 23, 603950 Nizhny Novgorod, Russia; ezagaynova@gmail.com

8 Chemistry Department, M.V. Lomonosov Moscow State University, 1 Leninskie Gory, 119991 Moscow, Russia

* Correspondence: frolova_a_a_2@staff.sechenov.ru

\begin{abstract}
The growing applications of tissue engineering technologies warrant the search and development of biocompatible materials with an appropriate strength and elastic moduli. Here, we have extensively studied a collagenous membrane (GSCM) separated from the mantle of the Giant squid Dosidicus Gigas in order to test its potential applicability in regenerative medicine. To establish the composition and structure of the studied material, we analyzed the GSCM by a variety of techniques, including amino acid analysis, SDS-PAGE, and FTIR. It has been shown that collagen is a main component of the GSCM. The morphology study by different microscopic techniques from nano- to microscale revealed a peculiar packing of collagen fibers forming laminae oriented at 60-90 degrees in respect to each other, which, in turn, formed layers with the thickness of several microns (a basketweave motif). The macro- and micromechanical studies showed high values of the Young's modulus and tensile strength. No significant cytotoxicity of the studied material was found by the cytotoxicity assay. Thus, the GSCM consists of a reinforced collagen network, has high mechanical characteristics, and is non-toxic, which makes it a good candidate for the creation of a scaffold material for tissue engineering.
\end{abstract}

Keywords: biomechanical properties; collagen membrane; AFM; SEM; tensile test; giant squid; Dosidicus Gigas; jumbo squid; outer tunic; tissue engineering

\section{Introduction}

The basic objective of tissue engineering consists of obtaining such a scaffold material that would promote complete or at least partial regeneration of internal organs, skin, vascular, bone, cartilage, and other tissues. For a construct to successfully engraft in the body, its parameters ought to be similar to those of the region in which the construct 
will function. The construct's biocompatibility, biodegradability, as well as mechanical properties determine its potential to substitute the corresponding live tissue in the body.

The interest to collagen-based materials is stipulated by the fact that collagen is biocompatible with the recipients' tissues, can biodegrade, is non-toxic, non-carcinogenic and non-immunogenic, and combines many characteristics of synthetic polymers (strength, stiffness, ability to form various supramolecular structures, etc.).

Currently, a plethora of pharmaceutical preparations and medical devices have been created using collagen as a base [1].

Collagen is one of basic natural materials which have application in tissue engineering [2-6]. In many types of connective tissue, it is a fibrillar protein and the main component responsible for the tissue integrity, shape, elasticity, and strength.

Connective tissue is present in all the organs and tissues in the body and comprises $\sim 60-90 \%$ of their weight. Such collagenous structures as tendons $[7,8]$ and ligaments [9] have a certain structural hierarchy of collagen to withstand intensive mechanical loads (extension and compression). The common idea about them has been that tendons and ligaments are structurally similar, if not identical [10]. Ligaments [10-12] and tendons [7,10,13] consist of tightly packed parallel collagen fibers. Ligaments differ from tendons by the predominance of elastic fibers; therefore, they are characterized by a lower strength but higher flexibility as compared to tendons. The distinctions between them stem from the connections they create; ligaments connect a bone with another bone, and tendons connect a muscle with a bone. A number of studies are dedicated to the restoration of tendon ruptures using different materials [14,15].

The skin is also an interesting and sophisticated collagen-based organ [16]. The skin structure resembles a net consisting of differently oriented collagen fibers [17-19]. One of the basic functions of the skin is to protect internal organs and tissues from mechanical injuries. Skin as a material exhibits a viscoelastic behavior, and its mechanical response to a stress involves both a viscous component related to energy dissipation and an elastic component related to energy storage [20,21]. Collagen fibers comprise $75 \%$ of the skin tissue dry weight [22], and it is those fibers that are responsible for the skin strength. The skin's mechanical properties are important for a number of applications, including surgery, dermatology, forensic medicine, etc. [23]. The problem of skin replacement and search of the appropriate materials has long been discussed (see, for example, a review [24]).

The anulus fibrosus, an outer fibrous ring of the intervertebral disc, is yet another example of a collagen-based tissue that undergoes mechanical stresses of various directions and has a corresponding collagen packing $[25,26]$.

The knowledge of the mechanical characteristics of tissues and organs, and the conditions in which they must function, help to create or select a material that would be appropriate for their complete or partial replacement $[27,28]$. The basic mechanical properties include the strength, stiffness, viscosity, elasticity, plasticity, brittleness, etc.

Table 1 presents examples of tissues with a certain collagen packing related to their mechanical properties and materials for tissue engineered constructs meant to replace such tissues. 
Table 1. Mechanical properties of some collagen-based tissues and materials for tissue engineered constructs.

\begin{tabular}{|c|c|c|c|c|}
\hline \multirow[t]{2}{*}{ Tissue/Material } & \multirow[t]{2}{*}{ Treatment } & \multicolumn{2}{|c|}{ Tensile Test Data } & \multirow[t]{2}{*}{ References } \\
\hline & & $\begin{array}{l}\text { Ultimate Tensile } \\
\text { Strength, UTS (MPa) }\end{array}$ & $\begin{array}{l}\text { Young's } \\
\text { Modulus } \\
(\mathrm{MPa})\end{array}$ & \\
\hline Human Skin & & $27.2 \pm 9.3 \mathrm{MPa}$ & $98.9 \pm 97 \mathrm{MPa}$ & {$[23,29]$} \\
\hline $\begin{array}{l}\text { Reconstructed anterior cruciate } \\
\text { ligament }(\mathrm{ACL}) \text { rabbit model }\end{array}$ & $\begin{array}{l}\text { Glutaraldehyde } \\
\text { cross-linked prostheses }\end{array}$ & $26 \mathrm{MPa}$ & & {$[30]$} \\
\hline $\begin{array}{l}\text { Reconstructed anterior cruciate } \\
\text { ligament }(A C L) \text { rabbit model }\end{array}$ & $\begin{array}{c}\text { Carbodiimide } \\
\text { cross-linked prostheses }\end{array}$ & $12 \mathrm{MPa}$ & & [30] \\
\hline $\begin{array}{l}\text { Reconstructed anterior cruciate } \\
\text { ligament }(A C L) \text { rabbit model }\end{array}$ & Sham-operated controls & $49 \pm 20 \mathrm{MPa}$ & & {$[30]$} \\
\hline Human patellar tendon & & $60-100 \mathrm{MPa}$ & $300-400 \mathrm{MPa}$ & [31] \\
\hline $\begin{array}{c}\text { Human native rotator cuff } \\
\text { tendon }\end{array}$ & & $11.5 \pm 5 \mathrm{MPa}$ & $50-170 \mathrm{MPa}$ & [32] \\
\hline $\begin{array}{c}\text { TSPC seeded knitted } \\
\text { silk-collagen sponge scaffold } \\
\text { for } \\
\text { functional shoulder repair } \\
\text { rabbit model }\end{array}$ & TSPC seeded & $\begin{array}{l}\text { Control group } \\
5.9 \pm 1 \mathrm{MPa} ; \\
\text { TCPC group } \\
8.3 \pm 1.5 \mathrm{MPa}\end{array}$ & $\begin{array}{l}\text { Control group } \\
44.3 \pm 12.1 \mathrm{MPa} \\
\text { TCPC group } \\
67.8 \pm 14.6 \mathrm{MPa}\end{array}$ & [33] \\
\hline Human Achilles tendon & & $40 \pm 8 \mathrm{MPa}$ & $1600 \pm 200 \mathrm{MPa}$ & [34] \\
\hline Rabbit Achilles tendon & & $4.5 \mathrm{MPa}$ & $45 \mathrm{MPa}$ & {$[14]$} \\
\hline Human fibrocartilage & & $10 \mathrm{MPa}$ & & [26] \\
\hline Human compact bone & & $0.03 \mathrm{MPa}$ & $\begin{array}{c}15,000 \mathrm{MPa} \\
\text { (Depending on type } \\
\text { and size of the bones) }\end{array}$ & [35] \\
\hline Human vaginal tissue & & $0.82-2.62 \mathrm{MPa}$ & & [36] \\
\hline Human cornea & & $3.81 \pm 0.4 \mathrm{MPa}$ & & [37] \\
\hline $\begin{array}{l}\text { DBP, decellularized bovine } \\
\text { pericardium }\end{array}$ & & $\begin{array}{l}\text { Along } 23 \mathrm{MPa} \\
\text { Across } 20 \mathrm{MPa}\end{array}$ & $\begin{array}{l}\text { Along } 120 \mathrm{MPa} \\
\text { Across } 50 \mathrm{MPa}\end{array}$ & [38] \\
\hline Normal human skin (NHS) & & $2.8 \mathrm{MPa}$ & & [39] \\
\hline $\begin{array}{c}\text { ASC from bovine hide } \\
\text { scaffolds by electrospinning }\end{array}$ & & $0.4 \mathrm{MPa}$ & & [39] \\
\hline $\begin{array}{l}\text { Un-crosslinked collagen film } \\
\text { from bovine tendon }\end{array}$ & & $10 \pm 0.5 \mathrm{MPa}$ & & {$[40]$} \\
\hline $\begin{array}{l}\text { Un-crosslinked collagen film } \\
\text { from (Coll type I) }\end{array}$ & & $37.7 \pm 4.5 \mathrm{MPa}$ & $1100 \pm 100 \mathrm{MPa}$ & [41] \\
\hline $\begin{array}{l}\text { Collagen films from rat tail } \\
\text { (Coll type I) }\end{array}$ & & $100 \mathrm{MPa}$ & $27 \mathrm{MPa}$ & [42] \\
\hline $\begin{array}{l}\text { Chitosan-AS collagen biofilms } \\
\text { from mantle } D \text {. gigas }\end{array}$ & & $33.5 \pm 4 \mathrm{MPa}$ & & {$[43]$} \\
\hline $\begin{array}{l}\text { Collagen fiber films from cattle } \\
\text { skin }\end{array}$ & & $\begin{array}{l}\text { Dry } 17.25 \pm 0.07 \mathrm{MPa} \\
\text { Wet } 2.61 \pm 0.05 \mathrm{MPa}\end{array}$ & & [44] \\
\hline $\begin{array}{l}\text { Fresh (non-treated) pulmonary } \\
\text { heart valves pigs }\end{array}$ & & $0.5 \pm 0.2 \mathrm{MPa}$ & & {$[45]$} \\
\hline
\end{tabular}

In the view of creating tissue engineered constructs with predefined mechanical properties, the mantle of squids attracts special attention, since these animals, living in the deep under great pressure, must have a robust musculature and outer coating to 
protect their internal organs. The morphological features of the squids' mantle affect the mechanisms of their locomotion [46].

Among many species of cephalopods, the Giant squid (Humboldt squid) represents the most important object of fishing, which covers 30\% of the world fishing volume and about $4 \%$ of the entire world market of squids [47]. It is the biggest of the known mollusks. This species of large predatory squids lives in the eastern Pacific region, along the Peru coast at depths of 200 to $700 \mathrm{~m}$. Its mantle can reach almost two meters in length, while its lifespan is only about 2 years, since the squid dies upon spawning [48].

A number of publications have appeared recently on the use of marine collagen, obtained, for example, from fish scales [49], mantle, fins, and tentacles of squids [50], and even sea cucumbers [51]. Uriarte-Montoya et al. (2010) described a film for application in the food and medical industries, prepared from collagen extracted from the mantle of the Giant squid of the Dosidicus gigas species [43]. Adamowicz et al. (2021) conducted a study on the use of the decellularized mantle of Loligo vulgaris squid in tissue engineering as a material for the urethra reconstruction [52]. Collagen-based materials prepared from the mantle of the Giant squid might also become a prospective carrier in tissue engineering, however, no studies on this idea have been reported so far.

Oliveira et al. (2021) discuss the application directions and advantages of marine collagen, as well as the need for the research in this area, aiming at strengthening this biopolymer's position on the world's collagen market [53]. Physically, biochemically, and spectroscopically, marine collagen is identical to mammalian collagen [54,55].

Application of mollusks for collagen production has other advantages, including safety from Creutzfeldt-Jakob disease, which is associated with collagen obtained from cattle, and no ethical or religious barriers.

In this study, our objective was to assess the possibility of using a material obtained from the mantle of the Giant squid, Dosidicus gigas, for the tasks of regenerative medicine, based on the data on its chemical composition, structural analysis, biomechanical properties, and cytotoxicity. The studied material represented a collagenous membrane prepared from the squid's outer tunic (hereafter, Giant Squid Collagenous Membrane, GSCM).

\section{Results}

2.1. Collagen Is a Basic Component of the GSCM

2.1.1. Amino Acid Analysis

According to the amino acid analysis, the content of hydroxyproline (Hyp) in the GSCM was 86.3 residues, proline (Pro)—91.3 residues per 1000 residues (Table 2). The Hyp percentage in the studied specimen was 10.13 weight $\%$.

The specimen also contained a large amount (330 per 1000 residues) of glycine (Gly). The weight percentage of Gly was $22.18 \%$. This finding is related to the fact that a molecule of collagen consists of a triple helix formed by three polypeptide helical strands, and each helical chain is formed by three-residue-long repeats, with glycine as one of the three residues. Thus, the primary structure of collagen is characterized by a large content of glycine. The high content of glutamic acid (Glu) in the specimen is explained by the presence of proline (Pro) since Pro is synthesized from glutamic acid. 
Table 2. Amino acid composition of the D. gigas CM.

\begin{tabular}{|c|c|c|c|c|c|}
\hline Name of Amino Acids & Abbreviation & Letter Code & $\begin{array}{c}\text { Molecular Mass, } \\
\text { g/mol }\end{array}$ & Residues per 1000 Residues & $\mathbf{w} \%$ * \\
\hline Alanine & Ala & A & 89.094 & 86.2 & 6.87 \\
\hline Arginine & Arg & $\mathrm{R}$ & 174.203 & 56.4 & 8.79 \\
\hline Aspartic acid & Asp & $\mathrm{D}$ & 133.104 & 62.9 & 7.49 \\
\hline Cysteine & Cys & $\mathrm{C}$ & 121.154 & 3.5 & 0.74 \\
\hline Glutamic acid & Glu & $\mathrm{E}$ & 147.131 & 86.4 & 11.38 \\
\hline Glycine & Gly & G & 75.067 & 330.0 & 22.18 \\
\hline Histidine & His & $\mathrm{H}$ & 155.156 & 7.7 & 1.07 \\
\hline Hydroxyproline & Hyp & $\mathrm{O}$ & 131.131 & 86.3 & 10.13 \\
\hline Hydroxylysine & Hyl & & 162.187 & 10.3 & 1.5 \\
\hline Isoleucine & Ile & I & 131.175 & 13.9 & 1.64 \\
\hline Leucine & Leu & $\mathrm{L}$ & 131.175 & 29.5 & 3.47 \\
\hline Lysine & Lys & $\mathrm{K}$ & 146.189 & 14.0 & 1.83 \\
\hline Methionine & Met & $\mathrm{M}$ & 149.208 & 10.4 & 1.39 \\
\hline Phenylalanine & Phe & $\mathrm{F}$ & 165.192 & 11.1 & 1.64 \\
\hline Proline & Pro & $\mathrm{P}$ & 115.132 & 91.3 & 9.4 \\
\hline Serine & Ser & $S$ & 105.093 & 41.1 & 3.86 \\
\hline Threonine & Thr & $\mathrm{T}$ & 119.119 & 27.9 & 2.97 \\
\hline Tyrosine & Tyr & Y & 181.191 & 6.4 & 1.04 \\
\hline Valine & Val & $\mathrm{V}$ & 117.148 & 24.9 & 2.61 \\
\hline \multirow[t]{2}{*}{ Total } & & & & 1000 & \\
\hline & Hyp/Hyl & & & 8.4 & \\
\hline
\end{tabular}

\subsubsection{SDS-PAGE}

The SDS-PAGE analysis showed four main bands in the studied GSCM (Figure 1). Two bands had the molecular weights of 133.3 and $151.6 \mathrm{kDa}$, and they were assigned to two $\alpha$-chains of collagen, $\alpha 1$ and $\alpha 2$. The two high-molecular components, with the weights of $295.7 \mathrm{kDa}$ and $300 \mathrm{kDa}$, were identified as a $\beta$-chain consisting of two $\alpha$-chains and a $\gamma$-chain consisting of three $\alpha$-chains, respectively.

\subsection{Hydration and Thermal Properties of the GSCM}

\subsubsection{FTIR Spectroscopy}

The IR spectrum of the GSCM (blue curve in Figure 2) shows bands at 876, 918, 939, $972,1030,1060,1080$, and $1119 \mathrm{~cm}^{-1}$, which are characteristic of carbohydrate moieties (CO stretching and COC stretching); an Amide III band at $1236 \mathrm{~cm}^{-1}$ (associated with CN stretching and NH deformation); bands positioned at 1336 and $1451 \mathrm{~cm}^{-1}$, attributable to methylene vibrations $\left(\mathrm{CH}_{2}\right.$ deformation and $\mathrm{CH}_{3}$ deformation); $\mathrm{N}-\mathrm{H}$ in-plane bend and the $\mathrm{C}-\mathrm{N}$ stretching vibrations at $1540 \mathrm{~cm}^{-1}$ (Amid II). The polypeptide backbone CO stretching vibration is found in the range of $1600-1700 \mathrm{~cm}^{-1}$ : bands at $1740 \mathrm{~cm}^{-1}$ due to carbonyl vibrations, and the one $1630 \mathrm{~cm}^{-1}$ due to Amide I. The spectrum shows bands at 2878 and $2927 \mathrm{~cm}^{-1}$ assigned to aliphatic chains ( $\mathrm{CH}$ stretching and $\mathrm{CH}_{3}$ stretching) an Amide B band at $3073 \mathrm{~cm}^{-1}$ (NH stretching), and a broad band at $3500-3300 \mathrm{~cm}^{-1}$ related to Amide A (NH stretching) and $\mathrm{OH}$ vibrations [56-60]. 


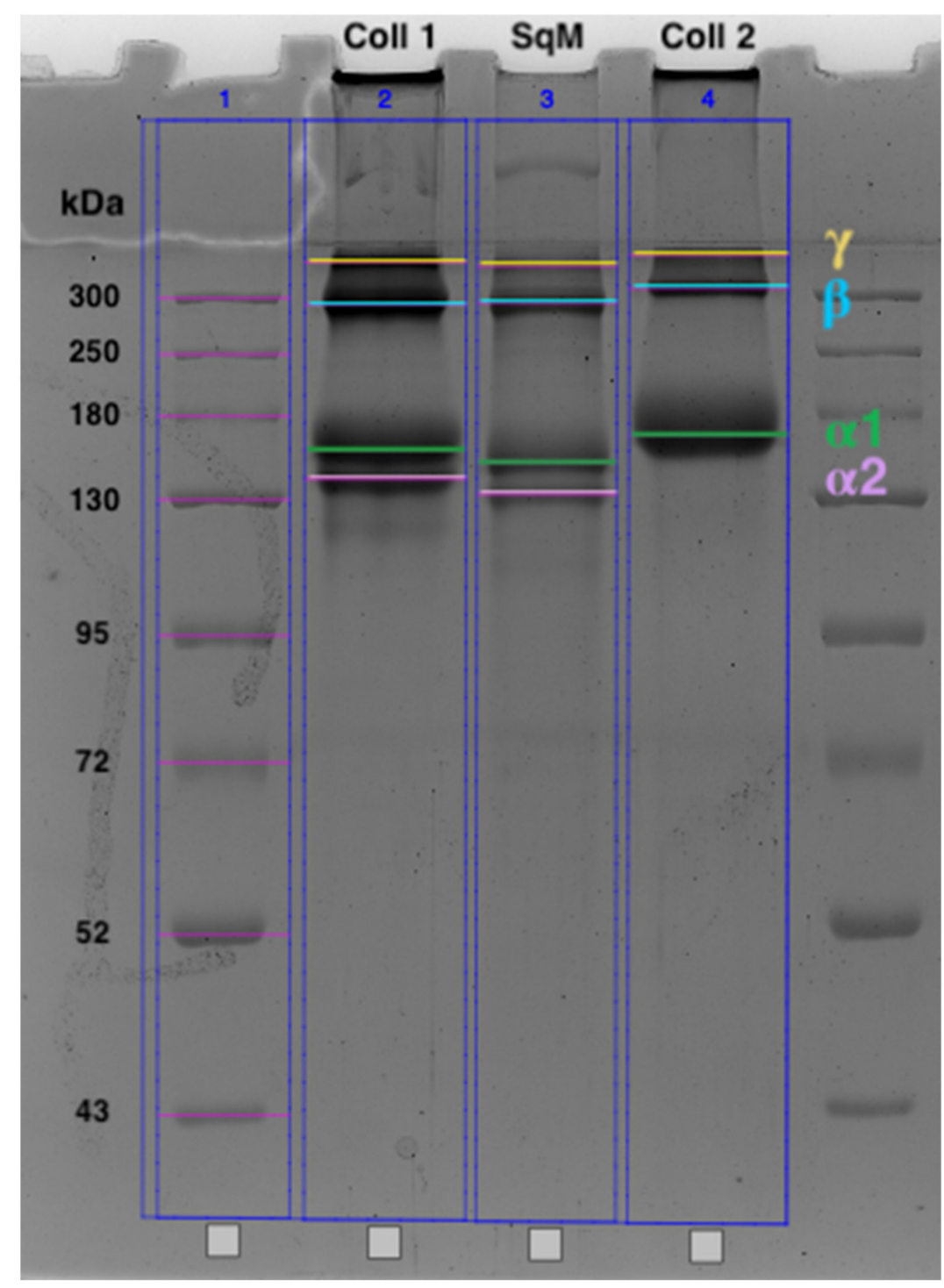

Figure 1. Evaluation of the GSCM collagen chains' electrophoretic mobility in 8\% PAAG under the denaturing and reducing conditions. Collagen Type I (Coll 1) and Type II (Coll 2) were used as collagen standards. SqM - collagen extracted from the GSCM. The high range protein ladder bands are shown in $\mathrm{kDa}$.

For comparison, the FTIR spectra of collagens Type I and Type II were examined [61]. The spectra of both samples are presented in Figure 2, and the band positions are presented in Table S1. FTIR confirmed a similar triple helical structure with the secondary $\alpha$-chain structure for all three samples [56]. The IR spectra of the GSCM and collagen type II differed slightly in regard to the bands at 1740, 2800-2930, and 3620-3690 $\mathrm{cm}^{-1}$ (associated with $\mathrm{OH}$ stretching and $\mathrm{H}$-bonding). From the general view of the spectra, one can assume that the GSCM belongs to collagen Type II, but the increased intensity of bands at 2930 and $1740 \mathrm{~cm}^{-1}$ indicates that it rather belongs to a mixture of collagens Type I and Type II. These results confirm the results of SDS-PAGE (see Section 2.1, Figure 1).

The position of the Amide I band in the GSCM spectrum is in agreement with the literature data on the Amide I band in the spectra of oligopeptides containing Gly, Pro, and Ala in various combinations, as well as the spectra of polyproline [60]. This is consistent with the results of the study of the amino acid composition, demonstrating that the main amino acids of the GSCM are Gly, Pro, Hyp, and Glu (see Section 2.1, Table 2). 


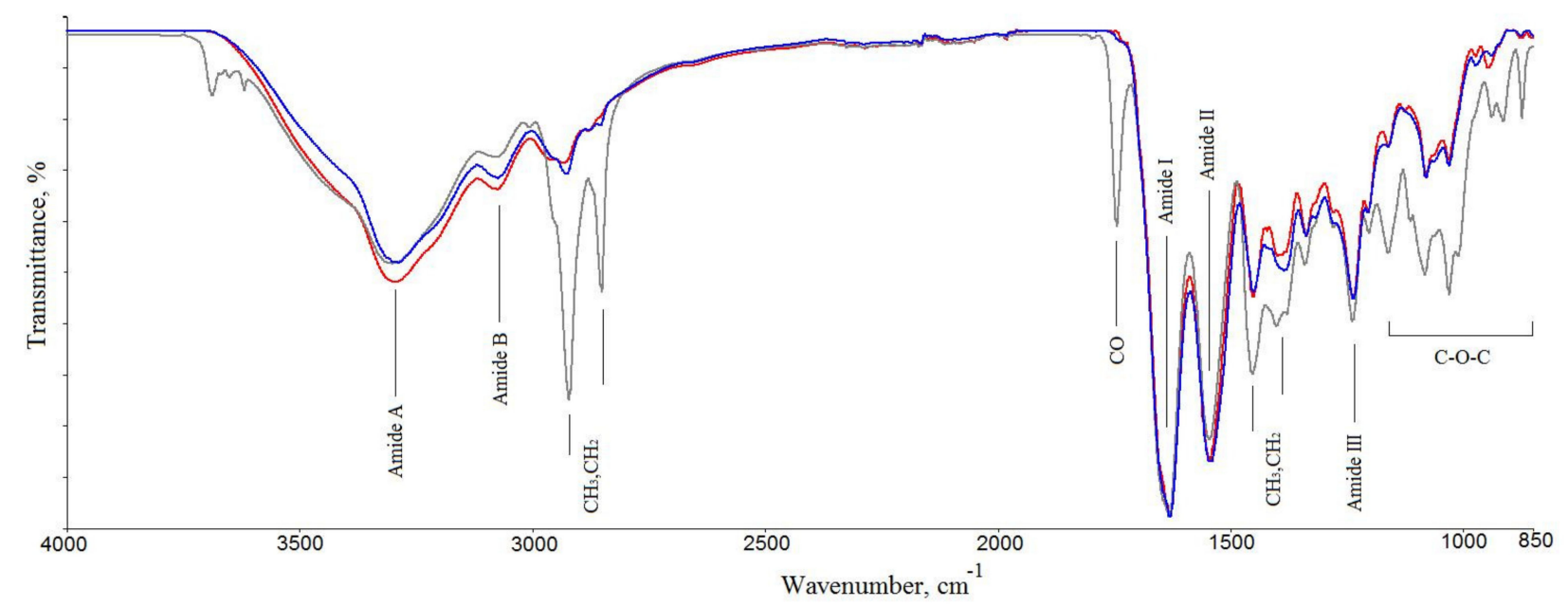

Figure 2. FT-IR spectra of the GSCM is the blue curve; collagen Type I is the gray curve; collagen Type II is the red curve.

\subsubsection{TGA/DSC Studies}

A typical weight loss vs. temperature curve (a thermogravimetric, TG curve), as well as a DSC curve, for the GSCM are displayed in Figure 3. In TG curves, there were two temperatures at which the onset of the thermal degradation occurred. The DSC curves showed two endothermic peaks. The broad endothermic peak in DSC curves in the temperature range of $50-170{ }^{\circ} \mathrm{C}$ is associated with thermal dehydration [62-64]. This process was accompanied by a $\sim 10 \%$ weight loss (the TG curve). The broad and multimodal endothermic peak in the temperature range of $220-330{ }^{\circ} \mathrm{C}$ is assigned to the collagen matrix thermal denaturation and destruction. The latter process was accompanied by a $\sim 65 \%$ weight loss (TG curves). According to [64], for dehydrated collagen type I, the endothermic peak of denaturation was observed at $\mathrm{Tdn}=225^{\circ} \mathrm{C}$. It can be assumed that, below the temperature of $\mathrm{Tdn} \sim 225-235{ }^{\circ} \mathrm{C}$, the interchain hydrogen bonds rupture, dehydrated collagens unfold, and amorphous polymers form. The second stage of destruction was observed at Tdst $>235^{\circ} \mathrm{C}$. In general, the GSCM TG and DSC curves were similar to those for collagenous materials $[62,64]$.

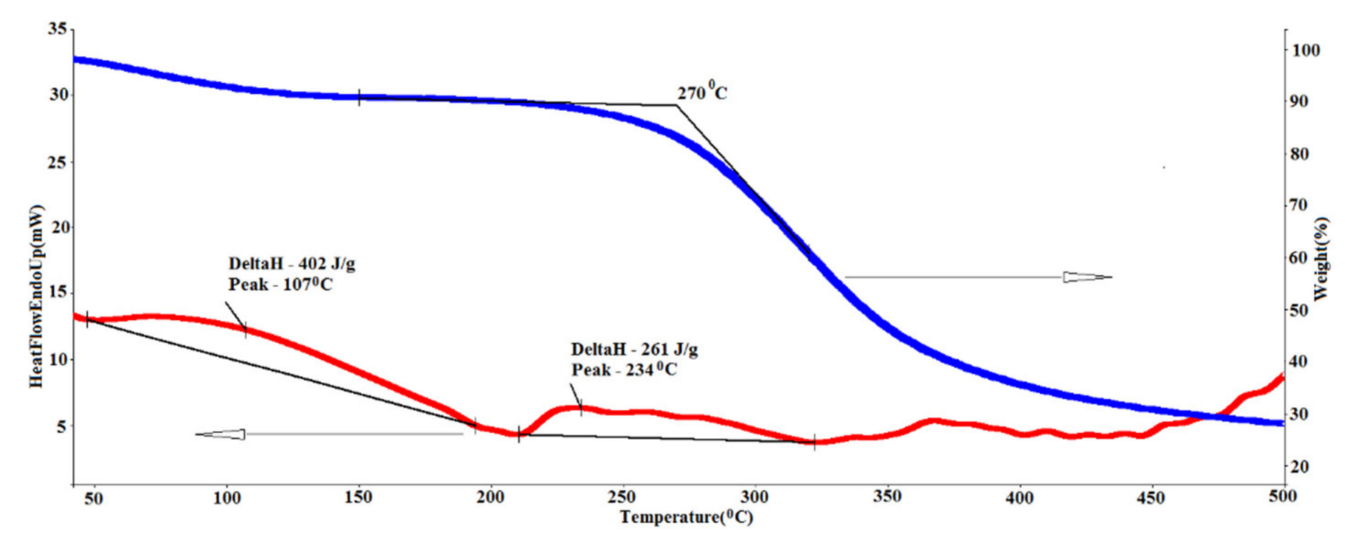

Figure 3. TG (blue) and DSC (red) curves for the GSCM.

\subsubsection{Shrinkage Temperature}

The shrinkage temperature of the GSCM was experimentally found at $58{ }^{\circ} \mathrm{C}$. The swelling degree was measured as $102 \%$ in distilled water and as $176 \%$ in PBS. The much higher degree of swelling in the PBS medium is due to the fact that ions present in the saline facilitate hydration of collagen fibers. 


\subsection{Morphological Properties of the GSCM}

\subsubsection{Histological Studies}

The histological studies of the GSCM cross-sections showed that the material had a layered structure that consisted of 8-12 tightly packed "laminae" with the total thickness of $\sim 50-70 \mu \mathrm{m}$ (Figure 4(A1,B1,C1,D1)). The thickness of each lamina was $\sim 5-7 \mu \mathrm{m}$. When stained with hematoxylin and eosin, the material of laminae had uniform eosinophilic staining (Figure 4(A1)). However, the picrosirius red stain (Figure 4(B1)), especially, when using phase contrast (Figure 4(C1)) and polarized light microscopy (Figure 4(D1)) showed that in some regions the material had a fibrillar structure due to poorly visible small collagen fibers oriented along the laminae. In the polarized light microscopy images, these fibers produced a bright glow in the material, testifying the birefringence (anisotropy) specific for oriented fibers in collagen.

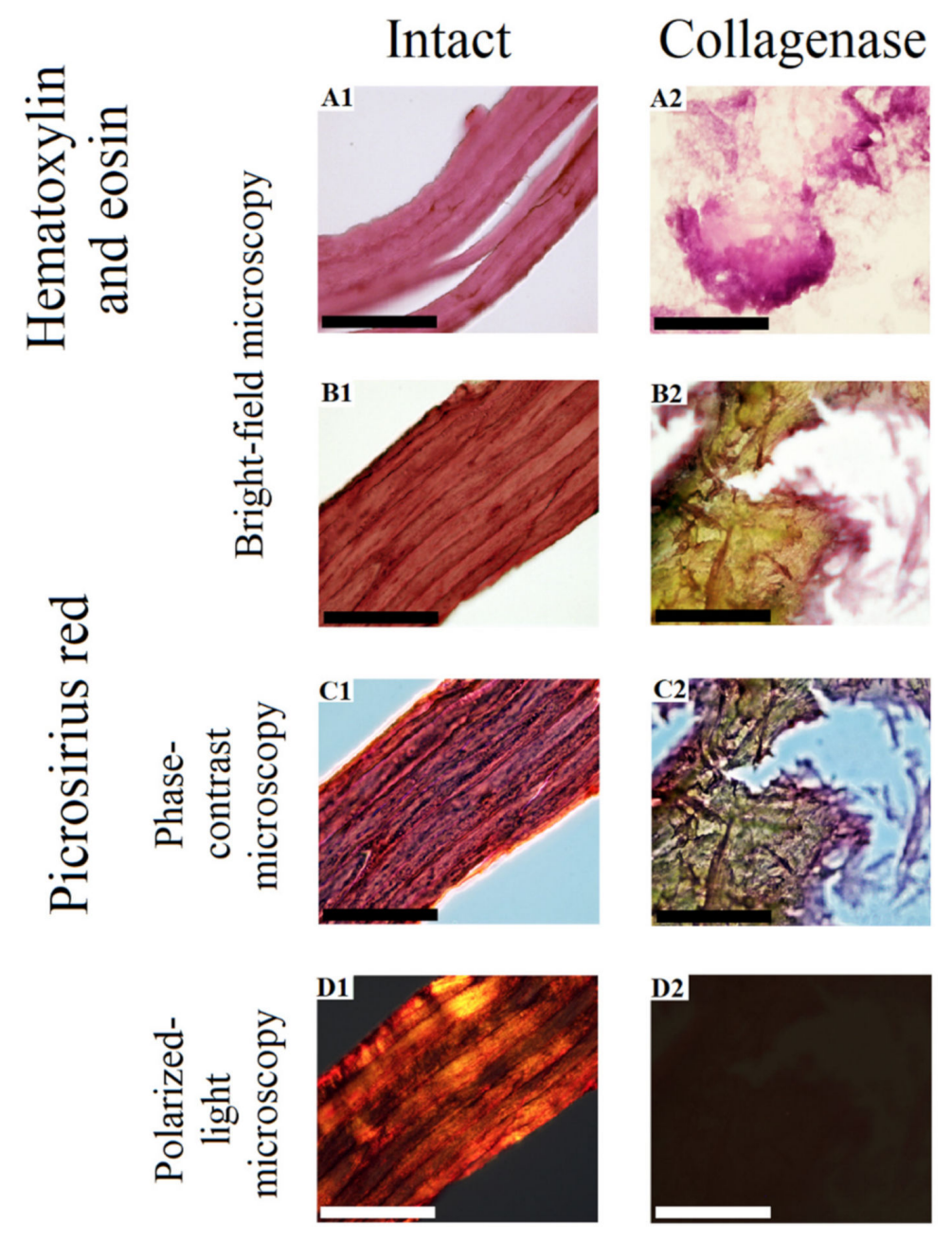

Figure 4. Morphological and optical characteristics of the GSCM before and after the collagenase treatment. (A1) As seen at a cross-section, the GSCM consists of parallel uniform pink (eosinophilic) layers- "laminae"; (A2) lysis of the material with homogenization, loss of crisp contours, and appearing purple (basophilic) regions; (B1) predominantly red staining of laminae with regions of poorly visible fine-fibred structure; (B2) loss of the red and appearance of yellow (picrinophilic) staining in most parts of the material with single loose and multidirectional red collagen fibers; (C1) a somewhat more visible fibrillar structure of the material than that in (B1); (C2) scattered collagen fibers among the picrinophilic material are more visible than they are in (B2); (D1) laminae produce a bright yellow-green, yellow-orange, and orange-red glow due to the collagen fibers within their structure; (D2) no material glow was noted; $\times 1000($ Scale bar $=50 \mu \mathrm{m})$. 


\subsubsection{Scanning Electronic Microscopy Studies (SEM)}

The SEM studies revealed that the GSCM surface had a multilayered basketweave structure, with laminae laid at different angles, which resembled a reinforcing mesh. The angle between the laminae was $\sim 60-90^{\circ}$ (Figure $5 a, b$ ).

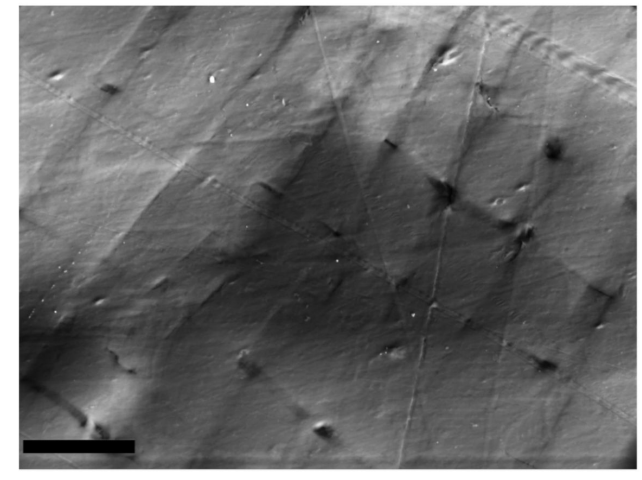

(a)

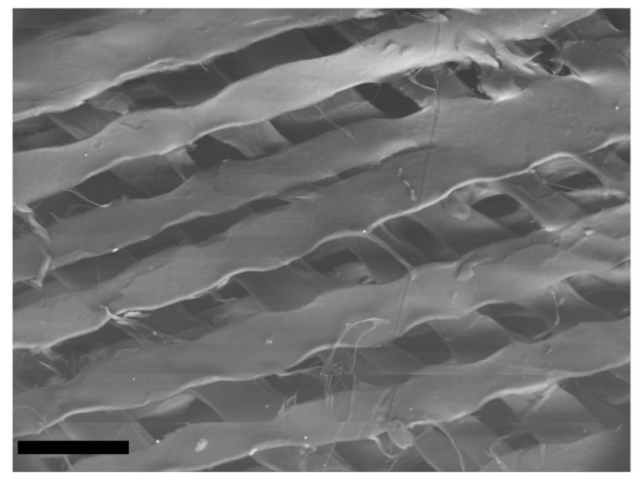

(b)

Figure 5. SEM-BSE images of the GSCM surface. (a) Native surface, and (b) a region inside a fracture zone of the material (Scale bar $=100 \mu \mathrm{m})$.

The reinforcing layers consisting of laminae have a definite mutual layer-by-layer orientation. Each layer represents a set of parallel laminae with the width of 38-50 $\mu \mathrm{m}$ and thickness of 4.0-4.5 $\mu \mathrm{m}$. In turn, each lamina consists of tightly packed parallel collagen fibers longitudinally packed along the whole lamina length (Figure 6a,b). Besides, there is a thin layer that covers the upper reinforcing layer with laminae (Figure 6c). This surface is extremely stable chemically (it was not damaged by the sample preparation procedure) and is formed by a randomly crossed motif of collagen fibers and fibrils.

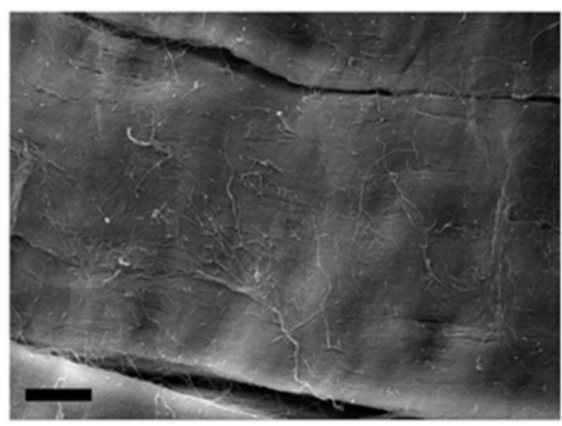

(a)

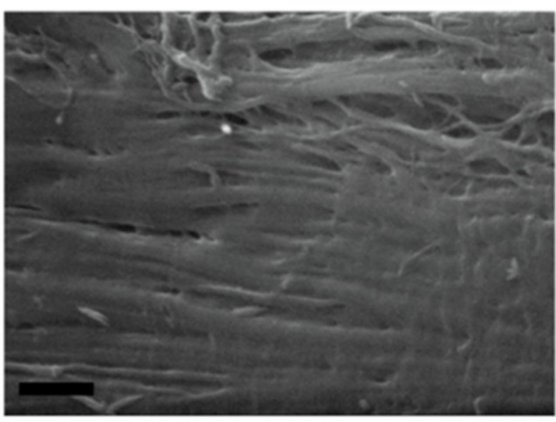

(b)

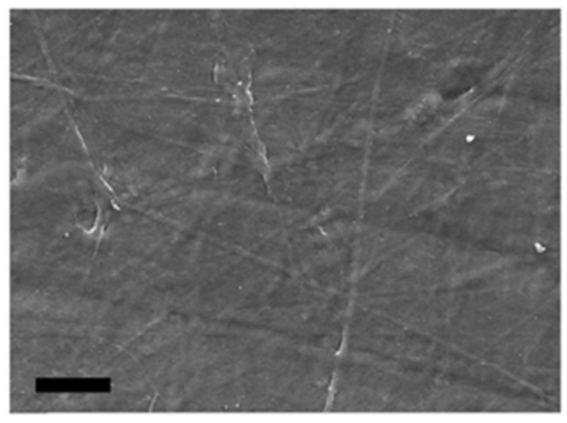

(c)

Figure 6. Microtopography of the dried GSCM (SEM-SE). (a) the surface of a lamina comprising the reinforcing layer (Scale bar $=10 \mu \mathrm{m}),(\mathbf{b})$ the enlarged fragment of the lamina surface (Scale bar $=1 \mu \mathrm{m})$, and (c) the layer covering the GSCM reinforcing layers (Scale bar $=20 \mu \mathrm{m})$.

We also studied the GSCM cross-section using SEM, which showed the layered structure, in agreement with the histological data. The SEM images (Figure 7a,b) demonstrate that laminae change their angle in each layer, thus making a basketweave multilayered collagen structure. 


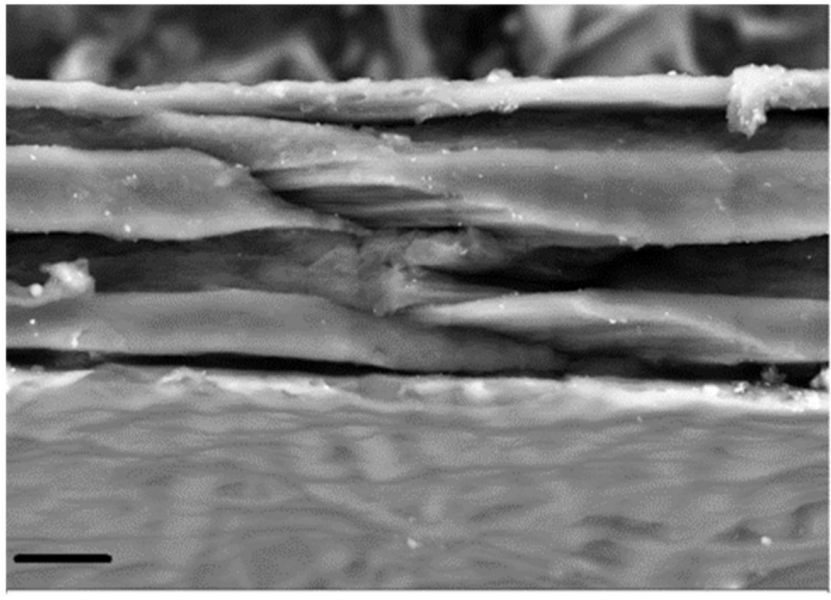

(a)

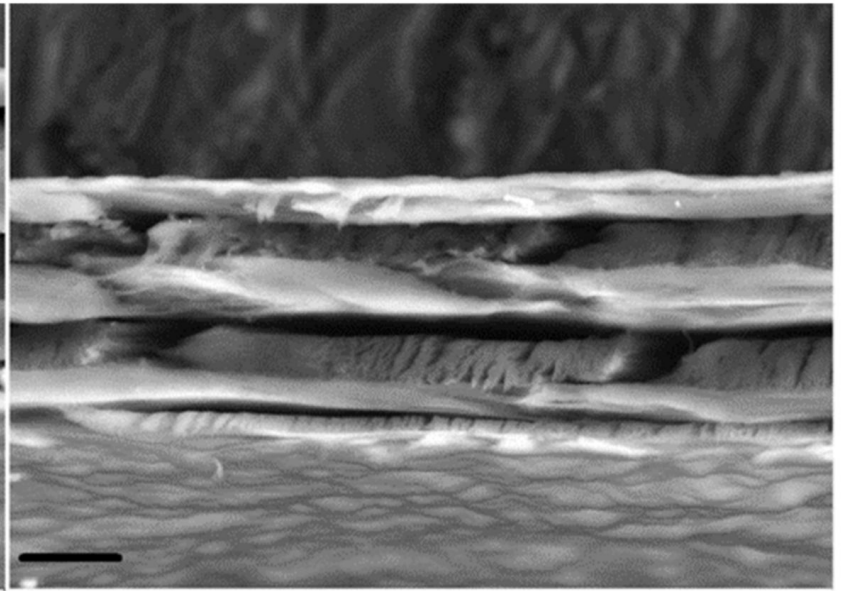

(b)

Figure 7. A SEM-BSE image of the GSCM cross-section. $(\mathbf{a}, \mathbf{b})$ Two different regions (Scale bar $=10 \mu \mathrm{m})$.

\subsubsection{Laser Scanning Microscopy (LSM) (Second Harmonics Generation Signal—SHG)}

The LSM studies revealed the SHG signal from collagen Type I and Type II in the sample. In consistency with SEM, it was found that collagen in the GSCM was bundled into laminae with the width of about $60 \mu \mathrm{m}$. Laminae located at different depths have different, up to perpendicular, mutual orientation (the angle of packing is $\sim 60-90^{\circ}$ ). Laminae consist of longitudinally positioned parallel collagen fibers (Figure $8 \mathrm{a}$ ). At the surface of some regions, bundles of collagen in the form of cords are found (Figure 8b). Similar structures were observed by SEM, as well (Figure 7a,c).
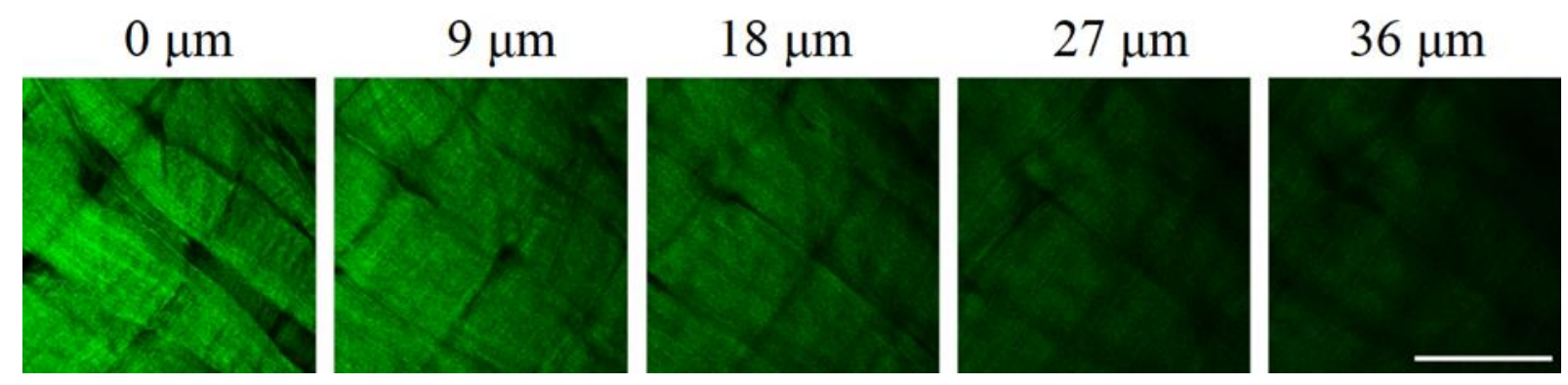

(a)

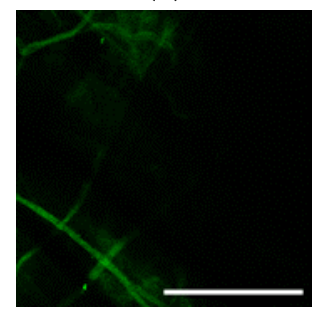

(b)

Figure 8. SHG images of the GSCM. (a) Collagen bundles in the form of laminae at different depths; (b) collagen in the form of cords at the sample's surface (Scale bar $=100 \mu \mathrm{m}$ ). The SHG signal from collagen is marked by green.

\subsubsection{Atomic-Force Microscopy (AFM)}

The microrelief of the GSCM surface was visualized using AFM. As seen from Figure 9, the GSCM surface has a fibrillar structure, with collagen fibers consisting of tightly packed longitudinally oriented fibrils. 


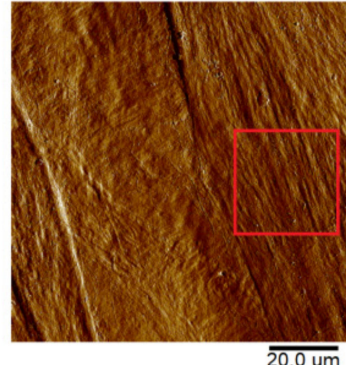

(a)

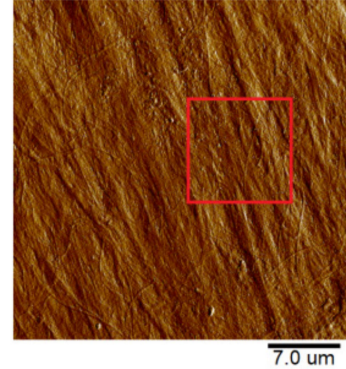

(b)

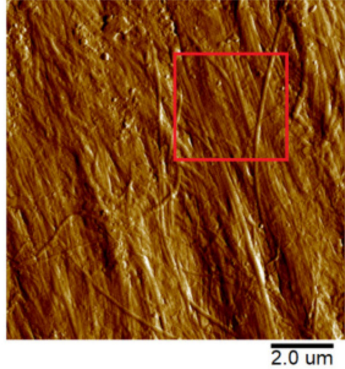

(c)

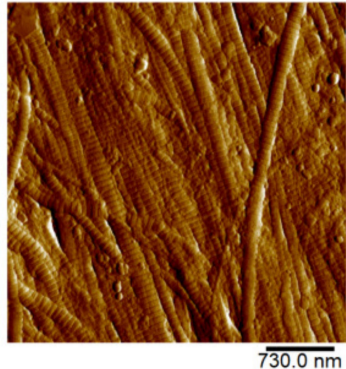

(d)

Figure 9. AFM topography of the GSCM with the sequential decrease of the scan size from the left to right image (increase of resolution): (a) $100 \times 100 \mu \mathrm{m}$; (b) $30 \times 30 \mu \mathrm{m}$; (c) $10 \times 10 \mu \mathrm{m}$; (d) $3 \times 3 \mu \mathrm{m}$. The samples' topography is presented using the Peak Force Error for the better detail resolution.

For comparison, we obtained the topography of the outer tunic of another squid species, B. magister, which has an essentially smaller size. As seen from Figure 10, the collagen structure of the outer membrane of this squid species is similar to that of the GSCM, with the corresponding scaling. The basketweave structure of both squids' reinforcing layers in the outer tunic is clearly visible in AFM images, which testifies the universal character of this structure. Since laminae comprising the reinforcing layer in the GSCM are rather wide $(40-50 \mu \mathrm{m})$ and located at a certain angle relative to each other, AFM cannot visualize the whole laminar motif of the GSCM, even at the largest available scan size, $100 \times 100 \mu \mathrm{m}$, so only one cell of the basketweave is seen (Figure 9a). However, for the small squid, $B$. magister, this laminar motif is clearly visible at a $50 \times 50 \mu \mathrm{m}$ scan (Figure 10a), since the B. magister has the proportionally smaller mantle and outer tunic thickness (Table 3).

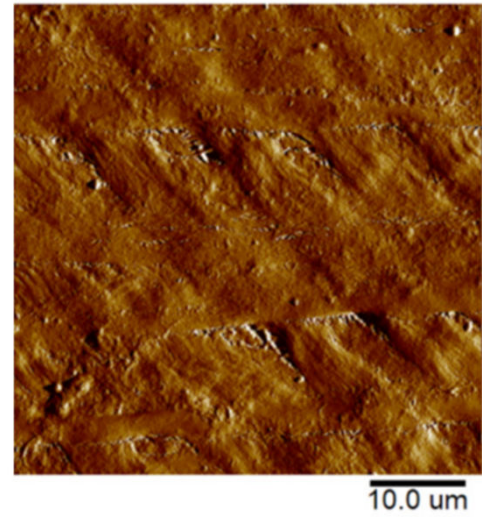

(a)

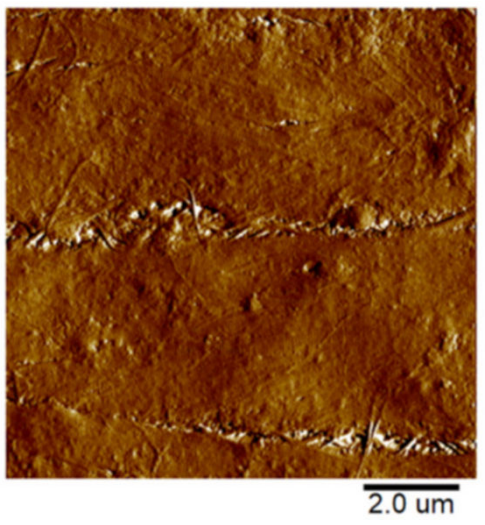

(b)

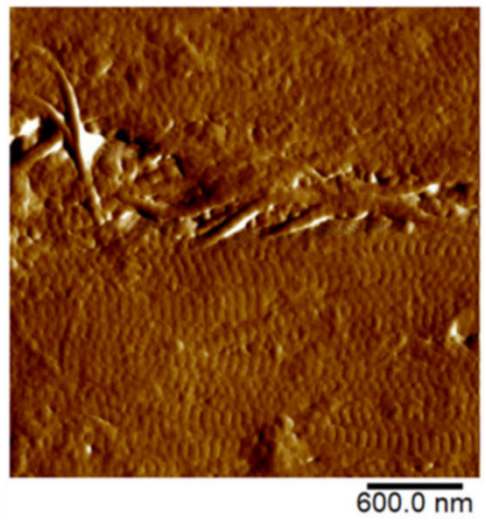

(c)

Figure 10. AFM topography of the collagenous membrane of a B. magister squid. From the left to right image (increase of resolution): (a) $50 \times 50 \mu \mathrm{m}$; (b) $10 \times 10 \mu \mathrm{m}$; (c) $3 \times 3 \mu \mathrm{m}$. The samples' topography is presented using the Peak Force Error for the better detail resolution.

With a higher resolution (a $3 \times 3 \mu \mathrm{m}$ scan, see more on the Figure 11), one can see the characteristic striation of collagen fibrils (D-period). The D-period is equal to $67 \mathrm{~nm}$, although the experimentally obtained values depend on the sample hydration [65]. 


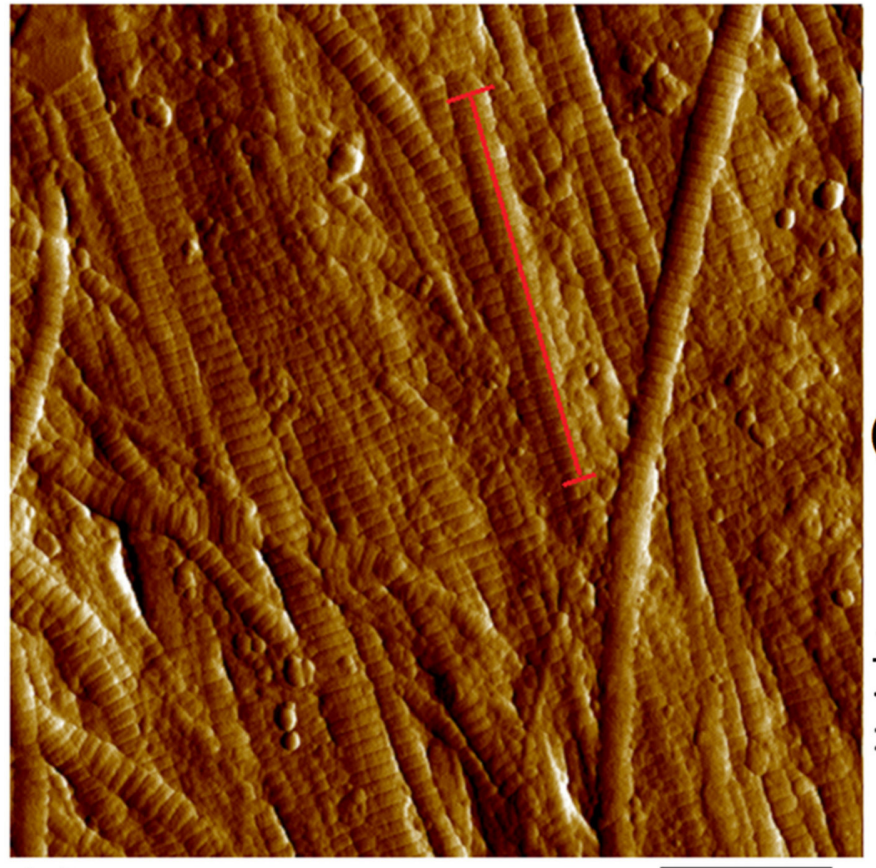

(a)
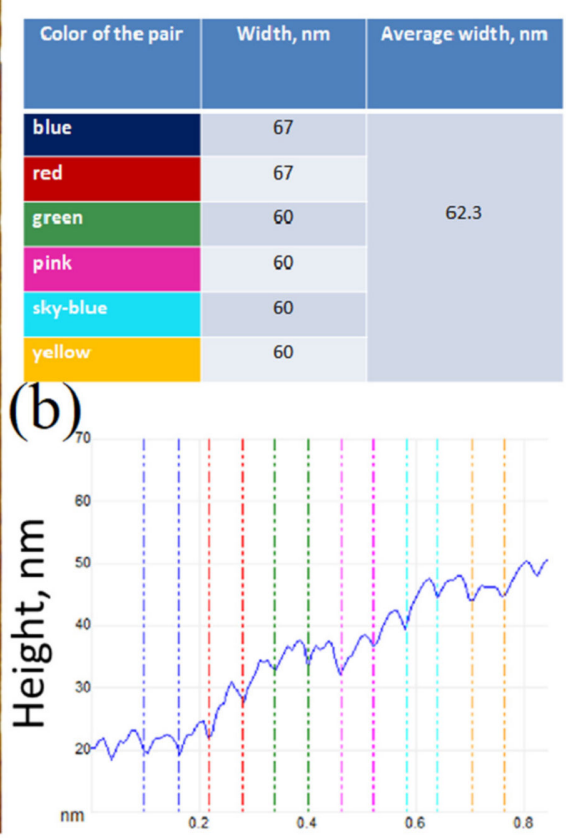

(c) Lateral position, $\mathrm{nm}$

Figure 11. Molecular packing of collagen in the GSCM (a) AFM topography (Peak Force Error channel), scan size is $3 \times 3$ $\mu \mathrm{m} ;(\mathbf{b}, \mathbf{c}) \mathrm{D}$ period of an individual fibril longitudinal section (red line on the topography image). The section shows the characteristic D-period of collagen $([66,67])$.

\subsection{Mechanical Properties of the GSCM}

\subsubsection{Uniaxial Stretching Tests}

The uniaxial stretching tests with the final sample rupture showed that the GSCM of D. gigas contained at least two basic directions of collagen fibers (Figure 12). The selected directions of collagen bundles may lead to the complex dependency of the GSCM mechanical properties on the deformation direction.

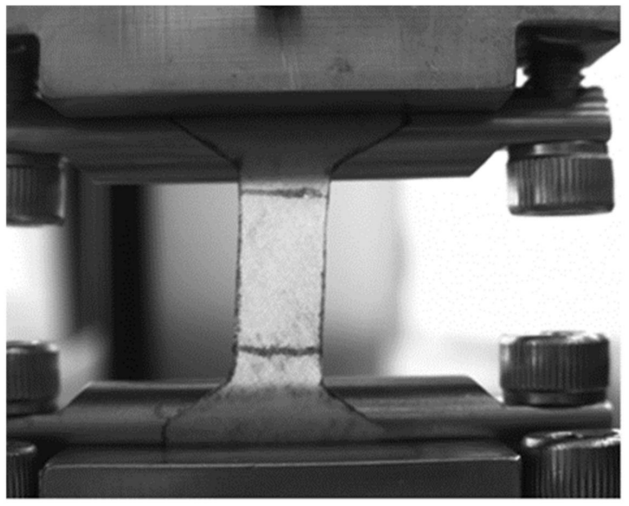

(a)

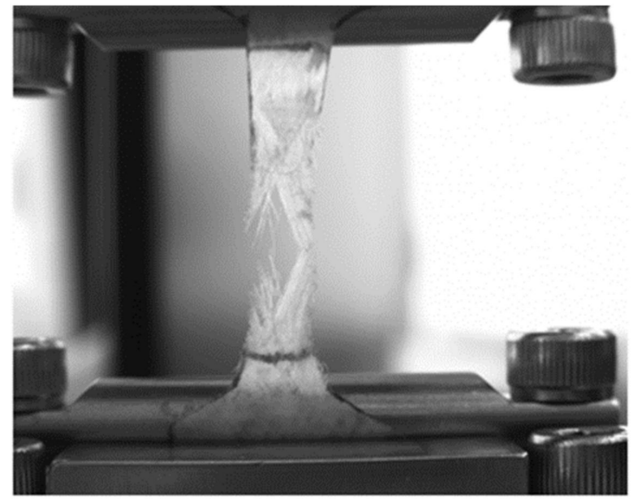

(b)

Figure 12. A uniaxial stretching test: (a) - start, (b) —end of test.

As seen from the results presented in Table 3, the studied samples of the GSCM of the $D$. gigas species had a rather high tensile strength for a biological material. The Young's modulus of a dry sample was $1.5 \pm 0.5 \mathrm{GPa}$, while, after 20-min-long hydration of the material, its Young's modulus drastically dropped to $20 \pm 6 \mathrm{MPa}$. The ultimate tensile strength of the hydrated sample also essentially decreased, however, the strain at rupture grew (to almost $50 \%$ ). 
For comparison, we tested the collagenous membrane of the $B$. magister squid, since it has a similar structure, as shown by AFM. The B. magister membrane demonstrated similar mechanical properties as well. Its Young's modulus was somewhat higher than that of the GSCM, while the ultimate tensile strength and maximum elongation at rupture were slightly lower (in the hydrated state). However, in general, the membrane from the $B$. magister squid is more deformable due to its lower thickness $(20 \mu \mathrm{m})$.

\subsubsection{Micromechanical Properties Studied by AFM}

As a result of the AFM-based nanoindentation studies at the micro- and nanoscale, the Young's modulus of the GSCM surface was measured as $4.1 \pm 0.5 \mathrm{MPa}$. The corresponding value for the $B$. magister squid was slightly higher, $6.1 \pm 0.5 \mathrm{MPa}$. The observed difference between the values at the macro- and microscale is related to the different packing and thickness of collagen structures at different levels. However, the values belong to the same order of magnitude.

Table 3. Mechanical properties of the GCSM and collagenous membranes from other squid species.

\begin{tabular}{|c|c|c|c|c|c|c|c|c|c|c|}
\hline Type of Squid & $\begin{array}{c}\text { DML, } \\
\text { cm }\end{array}$ & $\begin{array}{c}\mathrm{T}, \mu \\
\mathrm{m}\end{array}$ & $\underset{\mathrm{m}}{\mathrm{W}, \mu}$ & $\begin{array}{l}\mathrm{E}(\mathrm{w}) \\
\mathrm{MPa}\end{array}$ & $\begin{array}{l}\text { UTS(w), } \\
\text { MPa }\end{array}$ & $\begin{array}{c}\operatorname{Max} \varepsilon(w) \\
\%\end{array}$ & $\begin{array}{l}\mathrm{E}(\mathrm{d}) \\
\mathrm{GPa}\end{array}$ & $\begin{array}{l}\text { UTS(d), } \\
\text { MPa }\end{array}$ & $\begin{array}{c}\operatorname{Max} \varepsilon(d) \\
\%\end{array}$ & $\begin{array}{l}\mathrm{E}(\mathrm{w}) \\
\mathrm{MPa}\end{array}$ \\
\hline & & & & \multicolumn{6}{|c|}{ Macromechanical Properties } & Micromechanical Properties \\
\hline Dosidigus gigas & $\begin{array}{l}1500- \\
2000\end{array}$ & $50-70$ & $40-50$ & $20 \pm 6$ & $20 \pm 8$ & $47 \pm 9$ & $1.5 \pm 0.5$ & $80 \pm 20$ & $20 \pm 15$ & $4.1 \pm 0.5$ \\
\hline Loligo peale [68] & $30-50$ & $20-35$ & $2-7$ & No data & No data & No data & No data & No data & No data & No data \\
\hline $\begin{array}{l}\text { Berryteuthis } \\
\text { magister }\end{array}$ & 25 & 20 & $4-7$ & $54 \pm 17$ & $10 \pm 3$ & $27 \pm 7$ & $0.4 \pm 0.2$ & $28 \pm 9$ & $16 \pm 5$ & $6.5 \pm 0.5$ \\
\hline
\end{tabular}

DML—dorsal mantle length of squid; T—thickness of GSCM; W—width of lamina GSCM; E(w)—Young's modulus of wet GSCM; UTS(w) - ultimate tensile strength of wet GSCM; Max $\varepsilon(w)$-maximum elongation of wet GSCM; E(d)—Young's modulus of dry GSCM; UTS(d)—ultimate tensile strength of dry GSCM; Max $\varepsilon(d)$-maximum elongation of dry GSCM.

\subsection{Cytotoxicity and Biodegradability of the GSCM \\ 2.5.1. Viability Test}

To assess the potential GSCM cytotoxicity, cell viability and proliferation assays were performed. The MSC primary culture was chosen because MSCs are commonly applied in tissue engineering [69-71] and were shown to be more sensitive to toxic agents than 3T3 or L929 cell lines [72-74]. MSCs seeded at a concentration of 5000 cells per well and exposed to the GSCM extracts at any dilution showed neither reduction in the cell viability nor a decrease in the proliferation rate (Figure 13A). In contrast, both of the assays showed a significant drop (to $20 \%$ of the cell viability compared to the control cells) in the cell viability in the presence of SDS at a concentration of $0.05 \mathrm{mg} / \mathrm{mL}$ and higher (Figure 13B). Hence, the GSCM does not contain any cytotoxic compounds that could be released during cultivation. The adhesive properties of the GSCM were also shown to be appropriateMSCs successfully adhered to GSCM films, remained viable during 3 days of cultivation, and proliferated on them. The metabolic activity of cells cultured on the surface of the GSCM was slightly higher than that of the monolayer control (Figure 13C). However, proliferation of collagen-cultivated cells was inhibited in comparison to the monolayer cell culture grown on culture plastic, probably due to the different mechanical properties of the surface. The Live/Dead assay of the GSCM revealed normal MSC spindle-shaped morphology and outnumbering living cells relative to the dead ones (Figure 13D-G). Overall, despite the decreased proliferation rates of cells, the GSCM was shown to maintain the normal cell metabolic activity, proliferation capacity, and morphology both by the extraction and contact cytotoxicity test. 

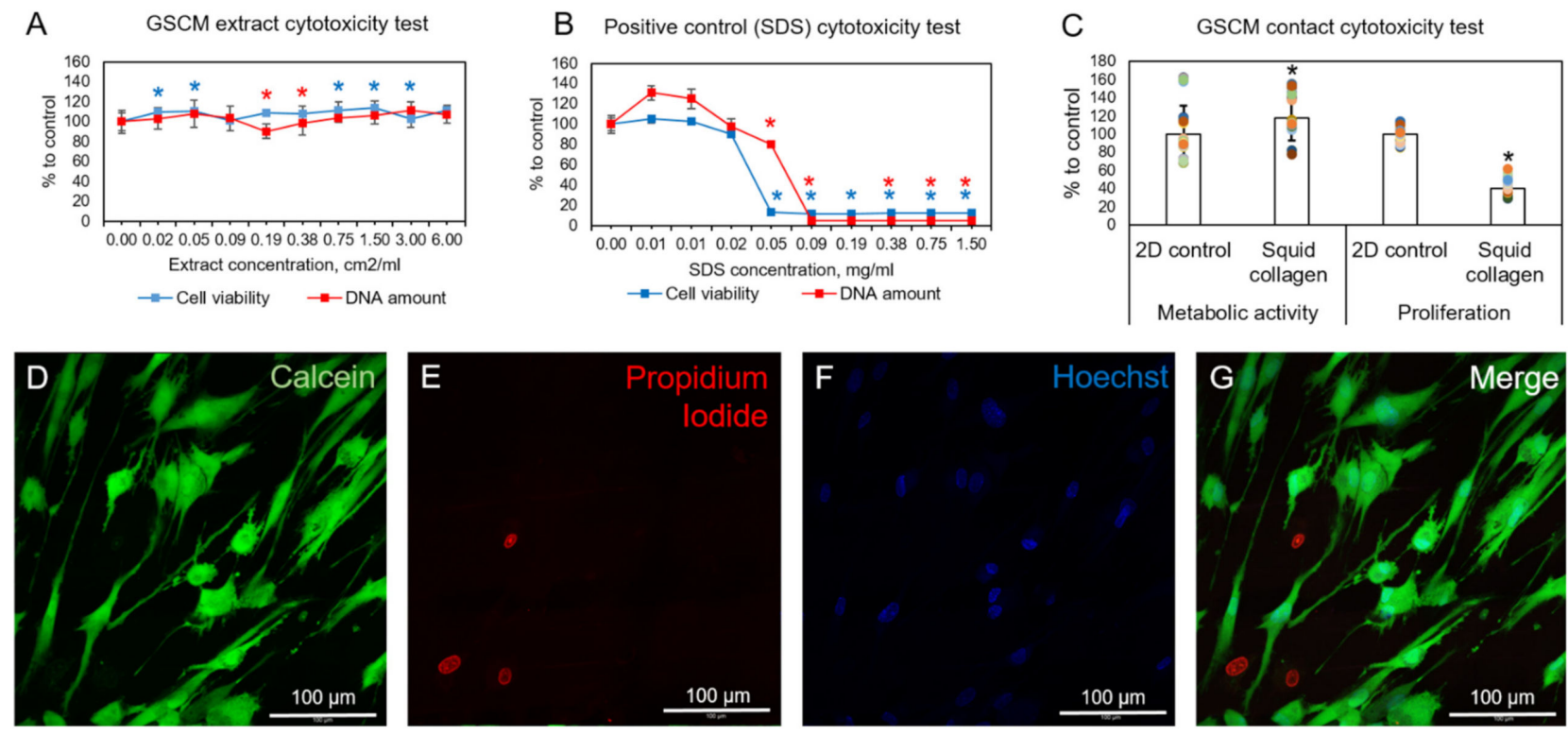

Figure 13. (A) -Elution test: AlamarBlue cytotoxicity assay and PicoGreen DNA assay of the GSCM extracts, 3 days of MSCs' cultivation, 5000 cells per well. (B)-AlamarBlue cytotoxicity assay and PicoGreen DNA assay of SDS (positive control), 3 days of MSCs cultivation, 5000 cells per well. (C)-AlamarBlue contact cytotoxicity assay and PicoGreen DNA assay of cells adhered to culture plastic (2D control) or GSCM, 3 days of cell cultivation, 20,000 cells per well. * $p<0.05$ relative to other groups. (D-G) - Live/Dead cell viability assay with nuclei staining (Hoechst, blue); live cells are stained with Calcein AM (green), and dead are stained with propidium iodide (red). At 7 days of cultivation, laser scanning confocal microscopy, scale bar is $100 \mu \mathrm{m}$.

\subsubsection{Resistance to Collagenase}

The sensitivity to collagenase was studied in order to estimate the biodegradability of the GSCM. The collagenase cleavage study showed that in $6 \mathrm{~h}$ the GSCM was digested by $85 \pm 5 \%$ from the initial weight.

The histological study of the GSCM samples treated with collagenase showed signs of their destruction in the form of the loss of the typical structure, as well as changes in the tinctorial and optical properties of the laminar material (see Section 2.3, Figure 4(A2,B2,C2,D2)). These signs included homogenization with lysis and appearing basophilic (Figure 4(A2)) and picrinophilic regions (Figure 4(B2)), as well as loosening and loss of orientation of collagen fibers (Figure 4(C2)) with the disappeared anisotropy (Figure 4(D2)). At the same time, in the picrosirius red-stained samples, the remaining material represented a homogenic picrinophilic mass, in which few chaotically located destroyed collagen fibers were seen.

\subsubsection{LAL Test}

To further assess the GSCM biosafety, we tested its pyrogenicity. The most common pyrogens are endotoxins derived from the cell walls of gram-negative bacteria. The LAL test is commonly applied to assess their concentration and is one of the two assays recognized by the U.S. Pharmacopeia (USP) for medical devices. For the GSCM extract, we revealed that the endotoxin level was $0.28 \mathrm{EU} / \mathrm{mL}$, which does not exceed the concentration permitted $(0.5 \mathrm{EU} / \mathrm{mL})[75,76]$. Therefore, the GSCM did not contain endotoxins able to induce a notable pyrogenic reaction. We also performed preliminary in vivo testing of GSCM samples implanted in rats (see Supplementary Information). It showed that the intact GSCM was still poorly compatible with the host tissues and caused notable inflammatory reaction. However, the GSCM treatment with supercritical carbon dioxide before implantation solved this problem, reducing the inflammatory reaction to only insignificant. 


\section{Discussion}

The results of the biochemical and structural studies confirm that collagen is a basic component of the GSCM material. The amino acid analysis showed a high content of Hyp, which is known as a detector for the presence of collagen [77]. Its weight percentage in the samples was $10.13 \%$, while the content of Pro and Hyp in the extracted collagen from the GSCM was $10.9 \%$ and $2.8 \%$, respectively [43]. The presence of Cys might indicate that the GSCM possibly contains traces of elastin [78]. Gauza-Włodarczyk et al. (2017) found a similar amino acid composition for bone collagen in [79].

The comparative SDS-PAGE analysis of the GSCM with collagen Type I and Type II revealed the similarity of the GSCM collagen to collagen Type I, based on the characteristic bands. Nam et al. (2008), in the study [80], described collagen extracted from a squid's skin and compared its physicochemical properties with those of collagen prepared from bovine tendons. The similarity between the two was found, and the squid collagen was classified as Type I.

FTIR demonstrated the presence of collagen Type II, also, in the GSCM. The DSC study showed that the GSCM collagen behaved similarly to both collagen types. The characteristic shrinkage temperature also confirmed the collagenous nature of the GSCM.

The extensive morphology study, including histology, SEM, LSM, and AFM, showed the presence of ordered collagen structures at various levels of organization. From the ultrastructure of fibrils to fibers and fiber bundles, they are characterized by tight packing, orientation, and formation of a basketweave from larger collagen units, laminae. Such a sophisticated arrangement of collagen structures is apparently related to the mechanical properties of the GSCM, such as high strength and Young's modulus.

Based on the SEM study, we have deduced a possible concept of the collagen arrangement in the studied material, displayed in Figure 14. The arrows in Figure 14 indicate which SEM-revealed feature corresponds to each component of the schematic structure. The structure and packing of laminae revealed by SEM are confirmed by the other structural techniques.

We have not found any published studies on the structure of the collagenous membrane from the Giant squid of the D. gigas species, based either on SEM or on any other visualization technique. However, the squid mantle is known to consist of three layers: muscle fibers and two collagenous membranes surrounding them (outer and inner tunic). There is one literature source in which Otwell et al. (1980) presented a sketch of the Loligo peale squid mantle with the specifics of all the three layers, as well as the corresponding SEM images [68].

The structural information, especially the unique architecture of collagen fibers in the GSCM, is of special importance in regard to its mechanical properties. The SEM, AFM, and LSM data show that the collagen laminae are arranged in a basketweave manner. We also have studied the structure of the same part from another squid species, B. magister. This small squid is easily available as a food product. Its mantle was separated from the muscle layer and studied with AFM. The AFM studies demonstrated a similar structure of the outer tunic for both squid species, despite a significant difference in their sizes. The characteristic features of the GSCM are repeated in the outer tunic of B. magister at a smaller scale. It is the structure that was observed in [68] for the Loligo peale species. In spite of essential differences in sizes, these squid species have similar morphological and structural features, as well as comparable mechanical characteristics (Table 3). 


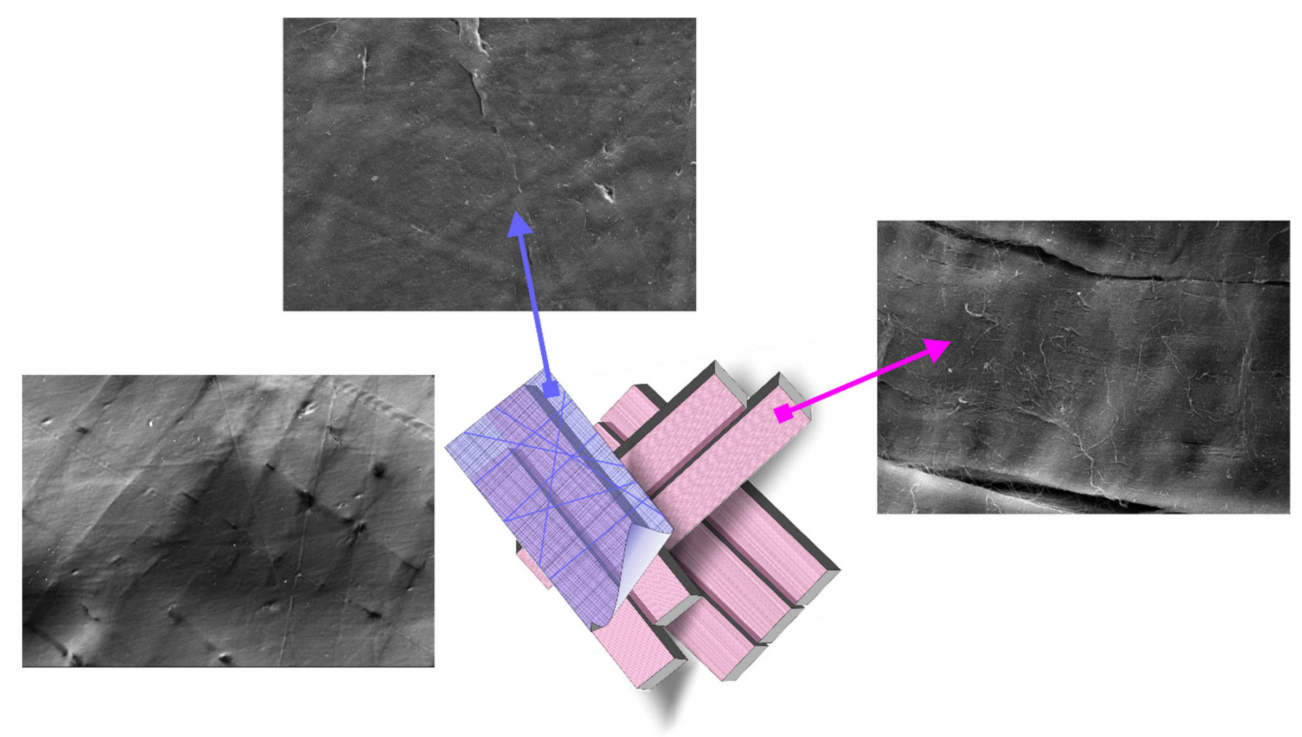

Figure 14. A possible concept of the arrangement of collagen fibers in the GSCM based on the SEM findings.

As the basic component of the squid mantle, collagen is related to the mechanism of the animal's locomotion. The collagenous membrane of the cephalopod has a basketweave structure that must work as a reinforcing frame in the squid's body, providing the appropriate strength and stiffness and allowing it to function at high depths.

Indeed, the data of the mechanical tests show rather high values of the tensile strength and Young's modulus for a biological collagen-based material [41,42,81]. A high value of strain at rupture is also notable. The GSCM mechanical characteristics at the microlevel measured by AFM are also high, which is associated with the tight collagen packing in the material in the form of a basketweave revealed by the microscopical visualization (SEM, LSM, ASM, histological staining). These findings are very important from the viewpoint of the potential GSCM applications in regenerative medicine.

A surgical material must have a good compatibility with the host organism tissues. Our cell experiments with gingival MSC and AlamarBlue, Live/Dead, and PicoGreen assays, as well as the LAL test and preliminary in vivo studies, have demonstrated that the GSCM does not exhibit any cytotoxic properties that testify its good biocompatibility.

The collagenase digestion experiment has additionally confirmed the collagenous nature of the material and proven that it can undergo almost complete destruction in vitro in as soon as $6 \mathrm{~h}$. After the treatment, a non-collagenous amorphous component is left, which binds to picric acid and hematoxylin, but it does not bind to picrosirius red and does not show birefringence. Most likely, this component consists of glycoproteins that bind collagen fibers together, thus providing their corresponding orientation and packing in each layer-lamina and also binding together laminae themselves. However, the presence of this non-collagenous component does not prevent the enzymatic action on collagen fibers in the material that may lead to its biodegradation in vivo.

Thus, the collagen nature, basketweave layered structure, good mechanical properties, absence of cytotoxicity, and ability to biodegrade make the GSCM a prospective candidate for tissue engineering applications.

\section{Materials and Methods}

\subsection{Material}

In this study, we used a commercial material-Aksolagen membrane-provided by the Akses Swiss company (Zug, Switzerland). Aksolagen membrane is a specially treated GSCM of Dosidicus gigas. The squid mantle consists of several layers (Figure 15), with the 
central muscle layer surrounded by two collagenous membranes (outer and inner tunics); the GSCM represents the outer tunic of the mantle.

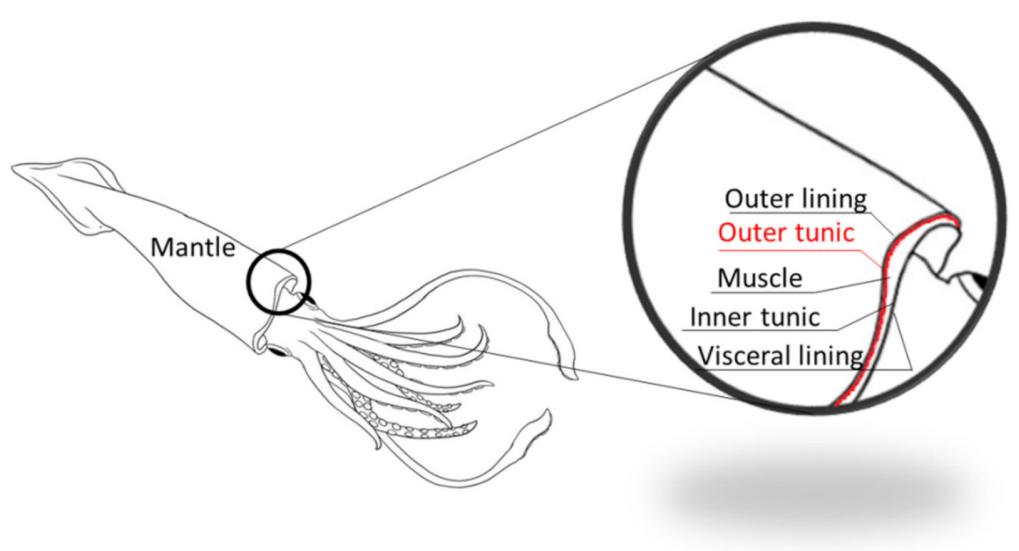

Figure 15. The D. gigas mantle and its inner structure.

We also studied the structure of the collagenous membrane of another squid species, a small squid B. magister. A frozen squid B. magister was purchased in a supermarket, thawed, and the collagenous membrane (outer tunic) was mechanically separated from the muscle layer of the mantle.

The thickness of the GSCM of D. gigas measured with a micrometer (a 5-10 N load) was $50 \pm 5 \mu \mathrm{m}$, and the thickness of the B. magister membrane was $25 \pm 5 \mu \mathrm{m}$.

\subsection{Amino Acid Analysis}

To study the GSCM composition, we conducted the amino acid analysis. The analysis was performed by ion-exchange chromatography, with the post column derivatization, using an L-8800 amino acid analyzer (Hitachi, Ltd., Tokyo, Japan) with a steel Hitachi Ion-Exchange Column 2622SC(PH) (Hitachi, Ltd., Tokyo, Japan) $4.6 \times 80 \mathrm{~mm}$. The column temperature was $57^{\circ} \mathrm{C}$, the flow rate was $0.4 \mathrm{~mL} / \mathrm{min}$, the charge volume was $50 \mu \mathrm{L}$, and the elution regime involved a stepwise gradient of eluents A (AAA PH-1 BufferAN0-8706 Merck Hitachi, Tokyo, Japan), B (AAA PH-2 Buffer-AN0-8707 Merck Hitachi, Tokyo, Japan), C (AAA PH-3 Buffer-AN0-8708 Merck Hitachi, Tokyo, Japan), D (AAA PH-4 Buffer-AN0-8709 Merck Hitachi, Tokyo, Japan), and E (0.2 M NaOH solution). As a calibration mixture, standard concentrated amino acid mixtures in ampoules were used (Amino Acid Standard Sigma Aldrich, St. Louis, MI, USA).

To prepare the studied solution, a dry sample was placed in a molybdenum glass ampoule, and $0.3 \mathrm{~mL}$ of a freshly prepared hydrolyzing mixture (concentrated hydrochloric and trifluoroacetic acids in a 2:1 ratio with the addition of $0.1 \% \beta$-mercaptoethanol Sigma Aldrich, St. Louis, MI, USA) was added. The sample was frozen, and the ampoule was evacuated and sealed. The hydrolysis was conducted at $155^{\circ} \mathrm{C}$ for $1 \mathrm{~h}$. After the hydrolysis, the ampoule was cooled, opened, and the content was quantitatively transferred $(0.1 \mathrm{~mL}$ of water twice) in a plastic $1.5 \mathrm{~mL}$ tube, then the hydrolyzing mixture was completely removed with a CentriVap vacuum concentrator (Labconco corporation, Kansas, MO, USA) at $50{ }^{\circ} \mathrm{C}$. The residual acids were removed by repeating twice the procedure of evaporation of small water portions $(0.1 \mathrm{~mL})$ added to the dry residue at $50{ }^{\circ} \mathrm{C}$. Then, $0.1 \mathrm{~N} \mathrm{HCl}$ was added to the dry residue, the mixture was centrifugated, and $0.1 \mathrm{~N} \mathrm{HCl}$ was added to the supernatant in a 10:1 ratio.

\subsection{Collagen Molecular Weight Estimation (SDS-PAGE)}

Following the collagen extraction, the protein concentration was evaluated by the gravimetric analysis. The sample was $\approx 100$-fold concentrated by ultrafiltration on a Microcon Centrifugal filter unit with a $10 \mathrm{kDa}$ molecular cut-off (MRCPRT010, Millipore, Burlington, MA, USA) to obtain the final collagen at $10 \mathrm{mg} / \mathrm{mL}$. Collagen from GSCM 
and Type I collagen from the cattle dermis were isolated using a protocol described in [82], while Type II collagen was isolated from the tracheal cartilage by a protocol described in [83] omitting the use of pepsin. An amount of $10 \mu \mathrm{g}$ of the proteins were diluted with an SDS-loading buffer supplemented with 100 mM DTT (20710, SERVA, Heidelberg, Germany) and heated at $95{ }^{\circ} \mathrm{C}$ for $5 \mathrm{~min}$. The samples were resolved by denaturing polyacrylamide gel electrophoresis in 5\% stacking and 8\% separating gel using a MiniPROTEAN Electrophoresis System (Bio-Rad, Hercules, CA, USA). The electrophoresis running conditions were as follows: at $15 \mathrm{~mA}$, until samples reached the separating gel, then at $30 \mathrm{~mA}$ until the front reached $0.5 \mathrm{~cm}$ from the gel edge. The gel was stained with Coomassie Blue R-250 (35051, SERVA, Heidelberg, Germany) and scanned with a ChemiDoc Imaging System (Bio-Rad, Hercules, CA, USA). The molecular weights of the visual bands were calculated in the ImageLab software against the molecular weight standards (Spectra Multicolor High Range Protein Ladder, SM1851, Fermentas, Waltham, MA, USA).

\subsection{IR-Spectroscopy}

The FTIR analysis of the initial components was carried out using a Spectrum Two FT-IR Spectrometer (PerkinElmer, Waltham, MA, USA) in the Attenuated Total Reflectance (ATR) mode. The spectrometer features were as follows: a high-performance, roomtemperature $\mathrm{LiTaO} 3 \mathrm{MIR}$ detector, a standard optical system with $\mathrm{KBr}$ windows for the data collection over a spectral range of $8300-350 \mathrm{~cm}^{-1}$ at a resolution of $0.5 \mathrm{~cm}^{-1}$. All the spectra were initially collected in the ATR mode and converted into the IR transmittance mode. The spectra of collagens were normalized using the intensity of the Amid I band as the internal standard.

\subsection{Differential Scanning Calorimetry (DSC)}

Differential scanning calorimetry (DSC) measurements were performed using an STA 6000 simultaneous thermal analyzer (PerkinElmer, Waltham, MA, USA). Samples for DSC experiments (about $10 \mathrm{mg}$ ) were encapsulated in standard PerkinElmer pans and heated in a nitrogen medium at a gas flow rate of $20 \mathrm{~mL} / \mathrm{min}$ and a linear heating rate of $10^{\circ} \mathrm{C} / \mathrm{min}$.

\subsection{Shrinkage Temperature}

A sample with the sizes of $3 \times 15 \mathrm{~mm}$ was placed in a special calibrated glass tube and immersed in a vessel filled with distilled water. The vessel was placed in a water bath. The water bath was heated from room temperature to the moment of the sample shrinkage $\left(\sim 60^{\circ} \mathrm{C}\right)$. The shrinkage temperature was determined as the temperature at which the beginning of the sample shrinkage was detected. The experiment was repeated thrice.

\subsection{Histological Study}

Intact and collagenase-treated fragments of the GSCM of D. gigas were fixed in a 10\% solution of neutral formalin, and $4 \mu \mathrm{m}$-thick histological sections were prepared using a standard technique.

The prepared sections were stained with hematoxylin and eosin and picrosirius red to reveal the collagen composition. The prepared slides were studied by optical (bright-field, phase contrast and polarized light) microscopy, and the images were captured with a LEICA DM4000 B LED microscope equipped with a LEICA DFC7000 T digital camera, using the LAS V4.8 software (Leica Microsystems, Heerbrugg, Switserland).

\subsection{Scanning Electron Microscopy (SEM)}

The GSCM structure was visualized using an EVO LS10 scanning electron microscope (Carl Zeiss Microscopy GmbH Jena, Germany). Two techniques for sample preparation and visualization were used.

The first protocol allowed general images of the samples in the most native state. Naturally dried samples were attached to the microscope stage with a special carbon 
adhesive tape. The observations were conducted in the low vacuum regime (EP, $70 \mathrm{~Pa})$ at the accelerating voltage of $20 \mathrm{kV}$ and the current of $94 \mathrm{pA}$ per sample. A detector for back-scattered electrons (BSE) was used. The images were obtained with the resolutions of $473.1 \mathrm{~nm} / \mathrm{px}$ and $508.8 \mathrm{~nm} / \mathrm{px}$. To achieve a satisfactory resolution during back-scattered electrons observations, a working distance of $4.5 \mathrm{~mm}$ was used.

For detailed evaluation of the structure, samples were fixed in neutral glutaric aldehyde, dehydrated (battery of alcohols from $20 \%$ to $97 \%$ and acetone), dried bypassing the critical point of $\mathrm{CO}_{2,}$ and coated with an $\mathrm{Au}-\mathrm{Pd}$ alloy. The so-prepared samples were attached to the microscope stage providing the charge outflow from the coated surface. The observations were conducted in the high vacuum regime at the accelerating voltage of $21 \mathrm{kV}$ and the sample current of $19 \mathrm{pA}$. The microtopography images were obtained using the detector for secondary electrons (SE). The $3072 \times 2304 \mathrm{px}$ images were captured with the resolutions of $89.89 \mathrm{~nm} / \mathrm{px}$ and $2697 \mathrm{~nm} / \mathrm{px}$.

\subsection{Laser Scanning Microscopy (Second Harmonics Generation, SHG Signal)}

The study was performed using a LSM 880 NLO laser scanning microscope (Carl Zeiss Microscopy GmbH Jena, Germany) equipped with a tunable Ti:Sa MaiTai HP laser (SpectraPhysics, Milpitas, CA, USA) with a pulse duration of less than $100 \mathrm{fs}$. The wavelength of $800 \mathrm{~nm}$ was used for the study, and the registration of the SHG signal was performed in the range of $370-420 \mathrm{~nm}$. The power of the probing radiation was about $9 \mathrm{~mW}$. The images were obtained using an oil immersion objective with the $40 \times$ magnification and numerical aperture of 1.3. The field of view was $212 \times 212 \mu \mathrm{m}$, and the resolution of images was $1024 \times 1024$ pixels. A series of images (z-stack) was acquired from the sample surface into the depth with the step of $9 \mu \mathrm{m}$, the orientation being parallel to the surface. For the convenience of perception, the acquired images were presented in the green palette.

\subsection{Atomic Force Microscopy (AFM)}

The morphological AFM studies of the surface were performed using an atomic force microscope (BioScope Resolve, Bruker, Billerica, MA, USA) combined with an Axio Observer inverted optical microscope (Carl Zeiss Microscopy GmbH Jena, Germany). A ScanAsyst Air cantilever (Bruker, Billerica, MA, USA) was used with a nominal spring constant $\mathrm{k}=0.4 \mathrm{~N} / \mathrm{m}$ and a nominal tip radius $\mathrm{r}=2 \mathrm{~nm}$, and scanning was performed on air in the PeakForce QNM regime. The collagen structures' periodicity was estimated with the Section function of the NanoScope Analysis v1.9 software (Bruker, Billerica, MA, USA).

\subsection{Uniaxial Stretching Test}

The uniaxial stretching tests for dry and hydrated samples were conducted using a Mach-1 v500c mechanical tester (Biomomentum, Laval, QC, Canada). For the hydration, samples were immersed in distilled water for $20 \mathrm{~min}$. The measurements were also performed in distilled water. Dumbbell-shaped fragments of the dry and hydrated GSCM were cut both in the tangential and radial directions in respect to the whole material area (with the circle diameter of $30 \mathrm{~cm}$ ). The working area of the fragments had the length of $15 \mathrm{~mm}$ and width of $5 \mathrm{~mm}$. The dry material thickness was $45 \mu \mathrm{m}$, while the thickness of the hydrated material was $60 \mu \mathrm{m}$. Before the test, the mechanical tester was calibrated using a standard sample provided by the manufacturer. Both ends of the experimental sample were tightly gripped in the clamps followed by gradual elongation at room temperature $\left(25^{\circ} \mathrm{C}\right)$ at a constant rate of $0.1 \mathrm{~mm} / \mathrm{s}$ until rupture. The mechanical parameters were calculated from the stress-strain curves according to the manufacturer's protocol. The data were averaged over 3 or more tests.

\subsection{Micromechanics by AFM}

The mechanical properties of the samples' surface were studied in fluid (distilled water) at room temperature $\left(25^{\circ} \mathrm{C}\right)$, after $20 \mathrm{~min}$ of hydration, using an atomic force microscope (BioScope Resolve, Bruker, Billerica, MA, USA). The sample micromechanics 
was obtained in the regime of nanoindentation over a preset map of $50 \times 50 \mu \mathrm{m}$ with the $32 \times 32$ pixels resolution, as described in [84]. A ScanAsyst Fluid cantilever (Bruker, Billerica, MA, USA) with a nominal spring constant of $0.95 \mathrm{~N} / \mathrm{m}$ and a nominal tip radius of $50 \mathrm{~nm}$ was precalibrated using a standard titanium sample. The deflection sensitivity was calibrated in the same conditions using a sapphire standard sample. The data were processed using the NanoScope Analysis v1.9 software(Bruker, Billerica, MA, USA) and averaged over 12 measurements.

\subsection{In Vitro Cytotoxicity Assays}

The biocompatibility and cytotoxicity tests were performed using the primary culture of mesenchymal stromal cells (MSCs) isolated from human gingival mucosa as described in [85]. The cells were cultivated in the medium that contained Dulbecco's Modified Eagle's Medium (DMEM)/F12 (1:1, Biolot, St. Petersburg, Russia), 10\% fetal calf serum (HyClone, Logan, UT, USA), L-glutamine (5 mg/mL, Gibco, Gaithersburg, MD, USA), insulin-transferrin-sodium selenite (1:100, Biolot, St. Petersburg, Russia), bFGF (20 ng/mL, ProSpec, Rehovot, Israel), and gentamycin (50 $\mathrm{g} / \mathrm{mL}$, Paneco, Moscow, Russia). Isolated cells were routinely checked with a SH800S microfluidic flow cytometer (Sony Biotechnology, San Jose, CA, USA) for the presence of mesenchymal surface markers (CD90, CD73, CD105) and absence of hematopoietic and endothelial markers (CD45, CD34, CD11b, CD19 and HLA-DR), according to [86]. The cells were cultivated in the standard conditions of $37{ }^{\circ} \mathrm{C}$ and $5 \% \mathrm{CO}_{2}$.

The cytotoxicity was analyzed via the elution and contact tests. In the first case, the extracts of the GSCM were prepared according to recommendations of ISO 10993-12. Briefly, 5000 cells per well of a 96-well plate were seeded $24 \mathrm{~h}$ before adding the extracts. To prepare extracts, GSCM films were incubated in the culture medium for $24 \mathrm{~h}$ at $37^{\circ} \mathrm{C}$. The thickness of a film was less than $0.5 \mathrm{~mm}$, and, therefore, in accordance with ISO 10993-12, the required sample's area was to be treated in a volume of $1 \mathrm{~mL}$ is $6 \mathrm{~cm}^{2}$. Cells were exposed to the maximum concentration of the extract $\left(6 \mathrm{~cm}^{2} / \mathrm{mL}\right)$ and its serial twofold dilutions. We used serial two-fold dilutions of $1.5 \mathrm{mg} / \mathrm{mL}$ sodium dodecyl sulphate (SDS) in a standard culture medium as a positive control. Cells cultivated in the standard culture medium were applied as a negative control. After $24 \mathrm{~h}$ of cultivation with the extract, SDS, or culture medium, the cell viability was assessed either with the AlamarBlue cell viability reagent (Invitrogen, Waltham, MA, USA) or with the Quant-iT PicoGreen kit (Invitrogen, Waltham, MA, USA). For the AlamarBlue metabolic activity assay, the cell culture medium was replaced with a 10\% reagent solution and incubated for $2 \mathrm{~h}$. Then, the fluorescence of samples was measured using a Victor Nivo spectrofluorometer (PerkinElmer, Waltham, MA, USA) at a $530 \mathrm{~nm}$ excitation wavelength and a $590 \mathrm{~nm}$ emission wavelength. The DNA amount was evaluated with the PicoGreen assay after 3 freeze-thaw cycles aimed at releasing DNA, following the manufacturer's instructions. The samples' fluorescence was estimated with the spectrofluorometer at a 480-nm excitation wavelength and a 520-nm emission wavelength.

For the contact cytotoxicity, 20,000 cells were seeded on a surface of the $1 \mathrm{~cm}^{2}$ GSCM films and cultivated for 3 days. Cells seeded on the culture plastic (monolayer culture) served as a control. Afterwards, the metabolic activity and DNA amount were measured as described above.

The morphology and viability of the cells seeded on the GSCM was visualized with the Live/Dead assay. Briefly, live cells were stained with calcein-AM (Sigma-Aldrich, St. Lois, MO, USA), dead cells were stained with propidium iodide (Thermofisher, Waltham, MA, USA), and nuclei were stained with Hoechst 33,258 (Thermofisher, Waltham, MA, USA). The images were obtained by laser confocal scanning microscopy using a LSM 880 instrument with Airyscan (Carl Zeiss Microscopy GmbH Jena, Germany).

All the samples were triplicated (plate wells for extract cytotoxicity and film samples for the contact cytotoxicity and Live/Dead assay). 


\subsection{Resistance to Collagenase}

The susceptibility to proteolytic degradation was studied in a Collagenase A (from $\mathrm{C}$ histolyticum) solution. Approximately $4 \mathrm{mg}$ (dry weight in triplicates) of the sample were weighed. To the weighed samples, $0.5 \mathrm{~mL}$ aliquots of a $2.5 \mathrm{mg} / \mathrm{mL}$ Collagenase A solution in the Tris buffer $(50 \mathrm{mmol} / \mathrm{L}, \mathrm{pH} 7.5)$ containing $10 \mathrm{mmol} / \mathrm{L}$ calcium chloride and $0.02 \mathrm{mg} / \mathrm{mL}$ sodium azide (Paneco, Moscow, Russia) were added. The samples were incubated at $37^{\circ} \mathrm{C}$ for $6 \mathrm{~h}$. Then, the samples were centrifuged at $605 \mathrm{~g}$ (3000 RPM) for $90 \mathrm{~s}$ (a MiniSpin microcentrifuge by Eppendorf Corporation, Hamburg, Germany). We used a low rotation speed and a short time of centrifugation in order to better preserve the structure integrity for the following histological analysis. Then, the material was washed from the residual collagenase with distilled water. The precipitate was carefully transferred using a micropipette to a coverslip for the following drying in an oven at $50{ }^{\circ} \mathrm{C}$ for $20 \mathrm{~h}$. Then, the dry residue was weighed using a WXTE ultramicrobalance (Mettler Toledo GmbH Urdorf, Switzerland). Finally, the weight loss was calculated by a paired comparison before and after the treatment.

\subsection{LAL Test}

The GSCM film was cut into $5 * 5$-mm pieces under aseptic conditions. The extracts were prepared in $1 \mathrm{~mL}$ of endotoxin-free water by continuous shaking for $24 \mathrm{~h}$ at $50{ }^{\circ} \mathrm{C}$. The endotoxin concentrations were measured using the Chromogenic Endotoxin Quantitation Kit (Thermo Fisher Scientific, Waltham, MA, USA) in accordance with the manufacturer's instruction. Briefly, we mixed $50 \mu \mathrm{L}$ of the extract or the endotoxin standard dilution (0.1, $0.25,0.5,0.1 \mathrm{U} / \mathrm{mL}$ ) and $50 \mu \mathrm{L}$ of endotoxin-specific Limulus Amebocyte Lysate (LAL) reagent in a well of a 96-well plate. The mixture was incubated for $10 \mathrm{~min}$ at $37^{\circ} \mathrm{C}$ and then $100 \mu \mathrm{L}$ of the chromogenic substrate was added and incubated for $6 \mathrm{~min}$ at $37^{\circ} \mathrm{C}$. The reaction was inhibited by adding $100 \mu \mathrm{L}$ of $25 \%$ acetic acid. The absorbance was measured at a wavelength of $405 \mathrm{~nm}$ using a microplate Victor Nivo spectrofluorometer (PerkinElmer, Waltham, MA, USA). The minimal detection level of the kit used was $0.1 \mathrm{EU} / \mathrm{mL}$ (EU—unit of measurement for endotoxin activity).

\section{Conclusions}

The literature analysis shows that the GSCM material has been very poorly studied, and no application in tissue engineering has been discussed so far. The results of our studies on the GSCM composition, structure, mechanical characteristics, cytotoxicity, and biodegradability testify that the GSCM of D. gigas is characterized by a high tensile strength and elasticity, along with a peculiar basketweave collagen structure and biocompatibility that allows the assumption that this material may be applicable in a number of tissue engineering fields (e.g., wound care materials, scaffolds for restoration of the musculoskeletal system, repair of hernias and the prolapse of pelvic organs, dental membranes, and other applications requiring good mechanical properties and slow degradation of the implanted material).

Upon the comparison with other squid species (in particular, B.magister), one may conclude that the GSCM structure is represented by a typical reinforcing mesh consisting of collagen structures and providing the high strength and Young's modulus. However, since the Giant squid D. gigas has a large size of the mantle and, respectively, a large lateral size of the GSCM, this material is more advantageous from the processing viewpoint.

Supplementary Materials: The following are available online at https: / www.mdpi.com/article / 10.3390/md19120679/s1, Table S1: Band positions for the GSCM, collagen Type I and II; Figure S1: Morphological and optical characteristics of the implanted intact GSCM; Figure S2: Morphological and optical characteristics of the implanted GSCM after the $\mathrm{scCO}_{2}$-treatment.

Author Contributions: Conceptualization, P.T. and S.K.; methodology, S.K., A.F. and E.I.; validation, P.T. and S.K.; formal analysis, A.M., E.G., P.B., V.E. and E.I.; investigation, A.F., N.A., I.N., A.M., E.G., Y.E., P.B., V.E. and A.K.; resources, A.F., N.A., I.N., A.M., E.G., Y.E., P.B., V.E., A.K., S.K., E.I., A.S., 
E.Z. and P.T.; data curation, A.F., S.K., E.I., A.S., E.Z. and P.T.; writing-original draft preparation, A.F., N.A., I.N., A.M., E.G., Y.E., P.B., V.E., A.K., S.K. and A.S.; writing-review and editing, A.F., A.S., S.K., E.I., E.Z. and P.T.; visualization, A.F., N.A., I.N., V.E., A.K. and A.S.; supervision, P.T.; project administration, P.T.; funding acquisition, P.T. All authors have read and agreed to the published version of the manuscript.

Funding: The study was financially supported by the Russian Science Foundation (18-15-00401).

Data Availability Statement: All the data supporting the conclusions of this article are included in this article.

Acknowledgments: The study was carried out using the unique scientific facility Transgenebank. The authors thank Anton Murashko (Moscow State University, Faculty of Physics) for drawing the graphical abstract. The authors are thankful to Anastasia Shpichka for her kind assistance with the cell experiments.

Conflicts of Interest: The authors declare no conflict of interest.

\section{References}

1. Fayzullin, A.L.; Shekhter, A.B.; Istranov, L.P.; Istranova, E.V.; Rudenko, T.G.; Guller, A.E.; Aboyants, R.K.; Timashev, P.S.; Butnaru, D.V. Bioresorbable collagen materials in surgery: 50 years of success. Sechenov Med. J. 2020, 11, 59-70. [CrossRef]

2. Cen, L.; Liu, W.; Cui, L.; Zhang, W.; Cao, Y. Collagen tissue engineering: Development of novel biomaterials and applications. Pediatr. Res. 2008, 63, 492-496. [CrossRef] [PubMed]

3. Parenteau-Bareil, R.; Gauvin, R.; Berthod, F. Collagen-based biomaterials for tissue engineering applications. Materials 2010, 3 , 1863-1887. [CrossRef]

4. Rekulapally, R.; Udayachandrika, K.; Hamlipur, S.; Sasidharan Nair, A.; Pal, B.; Singh, S. Tissue engineering of collagen scaffolds crosslinked with plant based polysaccharides. Prog. Biomater. 2021, 10, 29-41. [CrossRef]

5. Blackstone, B.N.; Gallentine, S.C.; Powell, H.M. Review collagen-based electrospun materials for tissue engineering: A systematic review. Bioengineering 2021, 8, 39. [CrossRef]

6. Huang, J.; Chen, L.; Gu, Z.; Wu, J. Red Jujube-Incorporated Gelatin Methacryloyl (GelMA) Hydrogels with Anti-Oxidation and Immunoregulation Activity for Wound Healing. J. Biomed. Nanotechnol. 2019, 15, 1357-1370. [CrossRef]

7. Nourissat, G.; Berenbaum, F.; Duprez, D. Tendon injury: From biology to tendon repair. Nat. Rev. Rheumatol. 2015, 11, 223-233. [CrossRef] [PubMed]

8. Kannus, P. Structure of the tendon connective tissue. Scand. J. Med. Sci. Sport. 2000, 10, 312-320. [CrossRef]

9. Mienaltowski, M.J.; Birk, D.E. Structure, Physiology, and Biochemistry of Collagens. In Progress in Heritable Soft Connective Tissue Diseases; Halper, J., Ed.; Springer: Dordrecht, The Netherlands, 2014; pp. 5-29.

10. Amiel, D.; Frank, C.; Harwood, F.; Fronek, J.; Akeson, W. Tendons and Ligaments: A Morphological and Biochemical Comparison A historical review of the evolution of the use of tendons as ligament substitutes reveals that these. J. Orthop. Res. 1984, 1, 251-265.

11. Frank, C.; Amiel, D.; Woo, S.L.Y.; Akeson, W. Normal ligament properties and ligament healing. Clin. Orthop. Relat. Res. 1985, 196, 15-25. [CrossRef]

12. Duthon, V.B.; Barea, C.; Abrassart, S.; Fasel, J.H.; Fritschy, D.; Ménétrey, J. Anatomy of the anterior cruciate ligament. Knee Surgery, Sport. Traumatol. Arthrosc. 2006, 14, 204-213. [CrossRef]

13. Franchi, M.; Fini, M.; Quaranta, M.; De Pasquale, V.; Raspanti, M.; Giavaresi, G.; Ottani, V.; Ruggeri, A. Crimp morphology in relaxed and stretched rat Achilles tendon. J. Anat. 2007, 210, 1-7. [CrossRef]

14. Bottagisio, M.; D’Arrigo, D.; Talò, G.; Bongio, M.; Ferroni, M.; Boschetti, F.; Moretti, M.; Lovati, A.B. Achilles tendon repair by decellularized and engineered xenografts in a rabbit model. Stem Cells Int. 2019, 2019. [CrossRef]

15. Song, Y.J.; Hua, Y.H. Tendon allograft for treatment of chronic Achilles tendon rupture: A systematic review. Foot Ankle Surg. 2019, 25, 252-257. [CrossRef]

16. Smith, L.T.; Holbrook, K.A.; Byers, P.H. Structure of the dermal matrix during development and in the adult. J. Invest. Dermatol. 1982, 79, 93-104. [CrossRef]

17. Armour, A.D.; Fish, J.S.; Woodhouse, K.A.; Semple, J.L. A comparison of human and porcine acellularized dermis: Interactions with human fibroblasts in vitro. Plast. Reconstr. Surg. 2006, 117, 845-856. [CrossRef] [PubMed]

18. Prasertsung, I.; Kanokpanont, S.; Bunaprasert, T.; Thanakit, V.; Damrongsakkul, S. Development of acellular dermis from porcine skin using periodic pressurized technique. J. Biomed. Mater. Res. Part B Appl. Biomater. 2008, 85, 210-219. [CrossRef]

19. Shoulders, M.D.; Raines, R.T. Collagen structure and stability. Annu. Rev. Biochem. 2009, 78, 929-958. [CrossRef]

20. Silver, F.H.; Freeman, J.W.; Devore, D. Viscoelastic properties of human skin and processed dermis. Ski. Res. Technol. 2001, 7, 18-23. [CrossRef] [PubMed]

21. Silver, F.H. Biological Materials: Structure, Mechanical Properties, and Modeling of Soft Tissues; NYU Press: New York, NY, USA, 1987; ISBN 9780814778609.

22. Wilkes, G.L.; Brown, I.A.; Wildnauer, R.H. The biomechanical properties of skin. CRC Crit. Rev. Bioeng. 1973, 1, 453-495. [PubMed] 
23. Ní Annaidh, A.; Bruyère, K.; Destrade, M.; Gilchrist, M.D.; Otténio, M. Characterization of the anisotropic mechanical properties of excised human skin. J. Mech. Behav. Biomed. Mater. 2012, 5, 139-148. [CrossRef]

24. Ruszczak, Z. Effect of collagen matrices on dermal wound healing. Adv. Drug Deliv. Rev. 2003, 55, 1595-1611. [CrossRef] [PubMed]

25. Gullbrand, S.E.; Ashinsky, B.G.; Lai, A.; Gansau, J.; Crowley, J.; Cunha, C.; Engiles, J.B.; Fusellier, M.; Muehleman, C.; Pelletier, M.; et al. Development of a standardized histopathology scoring system for intervertebral disc degeneration and regeneration in rabbit models-An initiative of the ORSspine section. JOR Spine 2021, 4, 1-12. [CrossRef]

26. Hiroshi, Y. Strength of Biological Materials; Williams \& Wilkins: Baltimore, MD, USA, 1970.

27. Huang, K.; Liu, G.; Gu, Z.; Wu, J. Tofu as excellent scaffolds for potential bone regeneration. Chinese Chem. Lett. 2020, 31, 3190-3194. [CrossRef]

28. Huang, K.; Hou, J.; Gu, Z.; Wu, J. Egg-White-/Eggshell-Based Biomimetic Hybrid Hydrogels for Bone Regeneration. ACS Biomater. Sci. Eng. 2019, 5, 5384-5391. [CrossRef]

29. Gallagher, A.J.; Ní Annaidh, A.; Bruyère, K.; Ottenio, M.; Xie, H.; Gilchrist, M.D. Dynamic Tensile Properties of Human Skin. In Proceedings of the 2012 IRCOBI Conference, Dublin, Ireland, 12-14 September 2012; pp. 1-6.

30. Dunn, M.; Tria, A.; Kato, P.; Bechler, J.; Ochner, R.; Zawadsky, J.; Silver, F.H. Anterior cruciate using a composite collagenous prosthesis histologic study in rabbits. Am. J. Sports Med. 1992, 20, 507-515. [CrossRef]

31. Butler, D.L.; Grood, E.S.; Noyes, F.R.; Zernicke, R.F.; Brackett, K. Effects of structure and strain measurement technique on the material properties of young human tendons and fascia. J. Biomech. 1984, 17, 579-596. [CrossRef]

32. Huang, C.Y.; Wang, V.M.; Pawluk, R.J.; Bucchieri, J.S.; Levine, W.N.; Bigliani, L.U.; Mow, V.C.; Flatow, E.L. Inhomogeneous mechanical behavior of the human supraspinatus tendon under uniaxial loading. J. Orthop. Res. 2005, 23, 924-930. [CrossRef]

33. Shen, W.; Chen, J.; Yin, Z.; Chen, X.; Liu, H.; Heng, B.C.; Chen, W.; Ouyang, H.W. Allogenous tendon stem/progenitor cells in silk scaffold for functional shoulder repair. Cell Transplant. 2012, 21, 943-958. [CrossRef] [PubMed]

34. Arya, S.; Kulig, K. Tendinopathy alters mechanical and material properties of the Achilles tendon. J. Appl. Physiol. 2010, 108, 670-675. [CrossRef]

35. Currey, J. The Structure and Mechanical Properties of Bone; Woodhead Publishing Limited: Sawston, UK, 2008 ; ISBN 9781845692049.

36. Rubod, C.; Boukerrou, M.; Brieu, M.; Jean-Charles, C.; Dubois, P.; Cosson, M. Biomechanical properties of vaginal tissue: Preliminary results. Int. Urogynecol. J. 2008, 19, 811-816. [CrossRef]

37. Zeng, Y.; Yang, J.; Huang, K.; Lee, Z.; Lee, X. A comparison of biomechanical properties between human and porcine cornea. J. Biomech. 2001, 34, 533-537. [CrossRef]

38. Grebenik, E.A.; Istranov, L.P.; Istranova, E.V.; Churbanov, S.N.; Shavkuta, B.S.; Dmitriev, R.I.; Veryasova, N.N.; Kotova, S.L.; Kurkov, A.V.; Shekhter, A.B.; et al. Chemical cross—linking of xenopericardial biomeshes: A bottom-up study of structural and functional correlations. Xenotransplantation 2019, 26, e12506. [CrossRef] [PubMed]

39. Powell, H.M.; McFarland, K.L.; Butler, D.L.; Supp, D.M.; Boyce, S.T. Uniaxial strain regulates morphogenesis, gene expression, and tissue strength in engineered skin. Tissue Eng. Part A 2010, 16, 1083-1092. [CrossRef] [PubMed]

40. Bose, S.; Li, S.; Mele, E.; Silberschmidt, V.V. Dry vs. wet: Properties and performance of collagen films. Part I. Mechanical behaviour and strain-rate effect. J. Mech. Behav. Biomed. Mater. 2020, 111, 103983. [CrossRef] [PubMed]

41. Koide, T.; Daito, M. Effects of Various Collagen Crosslinking Techniques on Mechanical Properties of Collagen Film. Dent. Mater. J. 1997, 16, 1-9. [CrossRef]

42. Habermehl, J.; Skopinska, J.; Boccafoschi, F.; Sionkowska, A.; Kaczmarek, H.; Laroche, G.; Mantovani, D. Preparation of ready-to-use, stockable and reconstituted collagen. Macromol. Biosci. 2005, 5, 821-828. [CrossRef]

43. Uriarte-Montoya, M.H.; Arias-Moscoso, J.L.; Plascencia-Jatomea, M.; Santacruz-Ortega, H.; Rouzaud-Sández, O.; Cardenas-Lopez, J.L.; Marquez-Rios, E.; Ezquerra-Brauer, J.M. Jumbo squid (Dosidicus gigas) mantle collagen: Extraction, characterization, and potential application in the preparation of chitosan-collagen biofilms. Bioresour. Technol. 2010, 101, 4212-4219. [CrossRef] [PubMed]

44. Wu, X.; Liu, A.; Wang, W.; Ye, R. Improved mechanical properties and thermal-stability of collagen fiber based film by crosslinking with casein, keratin or SPI: Effect of crosslinking process and concentrations of proteins. Int. J. Biol. Macromol. 2017, 109, 1319-1328. [CrossRef]

45. Theodoridis, K.; Müller, J.; Ramm, R.; Findeisen, K.; Andrée, B.; Korossis, S.; Haverich, A.; Hilfiker, A. Effects of combined cryopreservation and decellularization on the biomechanical, structural and biochemical properties of porcine pulmonary heart valves. Acta Biomater. 2016, 43, 71-77. [CrossRef]

46. Ward, D.V.; Wainwright, S.A. Locomotory aspects of squid mantle structure. J. Zool. 1972, 167, 437-449. [CrossRef]

47. FAO. The State of World Fisheries and Aquaculture 2018 Meeting the Sustainable Development Goals; FAO: Rome, Italy, 2018.

48. Ibáñez, C.M.; Sepúlveda, R.D.; Ulloa, P.; Keyl, F.; Pardo-Gandarillas, M.C. The biology and ecology of the jumbo squid Dosidicus gigas (Cephalopoda) in Chilean waters: A review. Lat. Am. J. Aquat. Res. 2015, 43, 402-414. [CrossRef]

49. Nagai, T.; Izumi, M.; Ishii, M. Fish scale collagen. Preparation and partial characterization. Int. J. Food Sci. Technol. 2004, 39, 239-244. [CrossRef]

50. Torres-Arreola, W.; Pacheco-Aguilar, R.; Sotelo-Mundo, R.R.; Rouzaud-Sández, O.; Ezquerra-Brauer, J.M. Partial characterization of collagen from mantle, fin, and arms of jumbo squid (Dosidicus gigas). Cienc. y Tecnol. Aliment. 2008, 6, 101-108. [CrossRef] 
51. Li, P.H.; Lu, W.C.; Chan, Y.J.; Ko, W.C.; Jung, C.C.; Le Huynh, D.T.; Ji, Y.X. Extraction and characterization of collagen from sea cucumber (Holothuria cinerascens) and its potential application in moisturizing cosmetics. Aquaculture 2020, 515, 734590. [CrossRef]

52. Adamowicz, J.; Kloskowski, T.; Stopel, M.; Gniadek, M.; Rasmus, M.; Balcerczyk, D. Materials Science \& Engineering C The development of marine biomaterial derived from decellularized squid mantle for potential application as tissue engineered urinary conduit. Mater. Sci. Eng. C 2021, 119, 111579. [CrossRef]

53. De Melo Oliveira, V.; Assis, C.R.D.; Costa, B.D.A.M.; de Araujo Neri, R.C.; Monte, F.T.D.; da Costa Vasconcelos, H.M.S.; França, R.C.P.; Santos, J.F.; de Souza Bezerra, R.; Porto, A.L.F. Physical, biochemical, densitometric and spectroscopic techniques for characterization collagen from alternative sources: A review based on the sustainable valorization of aquatic by-products. J. Mol. Struct. 2021, 1224, 129023. [CrossRef]

54. Rýglová, Š.; Braun, M.; Hříbal, M.; Suchý, T.; Vöröš, D. The proportion of the key components analysed in collagen-based isolates from fish and mammalian tissues processed by different protocols. J. Food Compos. Anal. 2021, 103. [CrossRef]

55. Benayahu, D.; Benayahu, Y. A Unique Marine-Derived Collagen: Its Characterization towards Biocompatibility Applications for Tissue Regeneration. Mar. Drugs 2021, 19, 419. [CrossRef] [PubMed]

56. Riaz, T.; Zeeshan, R.; Zarif, F.; Ilyas, K.; Muhammad, N.; Safi, S.Z.; Rahim, A.; Rizvi, S.A.A.; Rehman, I.U. FTIR analysis of natural and synthetic collagen. Appl. Spectrosc. Rev. 2018, 53, 703-746. [CrossRef]

57. Martínez Cortizas, A.; López-Costas, O. Linking structural and compositional changes in archaeological human bone collagen: An FTIR-ATR approach. Sci. Rep. 2020, 10,1-14. [CrossRef]

58. Belbachir, K.; Noreen, R.; Gouspillou, G.; Petibois, C. Collagen types analysis and differentiation by FTIR spectroscopy. Anal. Bioanal. Chem. 2009, 395, 829-837. [CrossRef] [PubMed]

59. Petibois, C.; Gouspillou, G.; Wehbe, K.; Delage, J.P.; Déléris, G. Analysis of type i and IV collagens by FT-IR spectroscopy and imaging for a molecular investigation of skeletal muscle connective tissue. Anal. Bioanal. Chem. 2006, 386, 1961-1966. [CrossRef]

60. De Campos Vidal, B.; Mello, M.L.S. Collagen type I amide I band infrared spectroscopy. Micron 2011, 42, 283-289. [CrossRef] [PubMed]

61. Ghodbane, S.A.; Dunn, M.G. Physical and mechanical properties of cross-linked type I collagen scaffolds derived from bovine, porcine, and ovine tendons. J. Biomed. Mater. Res._Part A 2016, 104, 2685-2692. [CrossRef] [PubMed]

62. Shanmugasundaram, N.; Ravikumar, T.; Babu, M. Comparative physico-chemical and in vitro properties of fibrillated collagen scaffolds from different sources. J. Biomater. Appl. 2004, 18, 247-264. [CrossRef]

63. Budrugeac, P.; Carşote, C.; Miu, L. Application of thermal analysis methods for damage assessment of leather in an old military coat belonging to the History Museum of Braşov-Romania. J. Therm. Anal. Calorim. 2017, 127, 765-772. [CrossRef]

64. Samouillan, V.; Delaunay, F.; Dandurand, J.; Merbahi, N.; Gardou, J.-P.; Yousfi, M.; Gandaglia, A.; Spina, M.; Lacabanne, C. The Use of Thermal Techniques for the Characterization and Selection of Natural Biomaterials. J. Funct. Biomater. 2011, 2, 230-248. [CrossRef]

65. Flint, M.H.; Merrilees, M.J. Relationship between the axial periodicity and staining of collagen by the Masson trichrome procedure. Histochem. J. 1977, 9, 1-13. [CrossRef]

66. Kotova, S.L.; Shekhter, A.B.; Timashev, P.S.; Guller, A.E.; Mudrov, A.A.; Timofeeva, V.A.; Panchenko, V.Y.; Bagratashvili, V.N.; Solovieva, A.B. AFM study of the extracellular connective tissue matrix in patients with pelvic organ prolapse. J. Surf. Investig. 2014, 8, 754-760. [CrossRef]

67. Baselt, D.R.; Revel, J.P.; Baldeschwieler, J.D. Subfibrillar structure of type I collagen observed by atomic force microscopy. Biophys. J. 1993, 65, 2644-2655. [CrossRef]

68. Otwell, W.; Giddings, G. Scanning electron microscopy of squid, Loligo pealei: Raw, cooked, and frozen mantle. Mar. Fish. Rev. 1980, 42, 67-72.

69. Han, Y.; Li, X.; Zhang, Y.; Han, Y.; Chang, F.; Ding, J. Mesenchymal Stem Cells for Regenerative Medicine. Cells 2019, 8, 886. [CrossRef] [PubMed]

70. Freeman, F.E.; Kelly, D.J. Tuning alginate bioink stiffness and composition for controlled growth factor delivery and to spatially direct MSC Fate within bioprinted tissues. Sci. Rep. 2017, 7, 1-12. [CrossRef]

71. Bikmulina, P.Y.; Kosheleva, N.V.; Shpichka, A.I.; Efremov, Y.M.; Yusupov, V.I.; Timashev, P.S.; Rochev, Y.A. Beyond 2D: Effects of photobiomodulation in 3D tissue-like systems. J. Biomed. Opt. 2020, 25, 1. [CrossRef] [PubMed]

72. Paterson, T.E.; Shi, R.; Tian, J.; Harrison, C.J.; De Sousa Mendes, M.; Hatton, P.V.; Li, Z.; Ortega, I. Electrospun scaffolds containing silver-doped hydroxyapatite with antimicrobial properties for applications in orthopedic and dental bone surgery. J. Funct. Biomater. 2020, 11, 58. [CrossRef] [PubMed]

73. Sindhu, K.R.; Bansode, N.; Rémy, M.; Morel, C.; Bareille, R.; Hagedorn, M.; Hinz, B.; Barthélémy, P.; Chassande, O.; Boiziau, C. New injectable self-assembled hydrogels that promote angiogenesis through a bioactive degradation product. Acta Biomater. 2020, 115, 197-209. [CrossRef]

74. Merlin Rajesh Lal, L.P.; Suraishkumar, G.K.; Nair, P.D. Chitosan-agarose scaffolds supports chondrogenesis of Human Wharton's Jelly mesenchymal stem cells. J. Biomed. Mater. Res._Part A 2017, 105, 1845-1855. [CrossRef] [PubMed]

75. Keane, T.J.; Saldin, L.T.; Badylak, S.F. Decellularization of Mammalian Tissues: Preparing Extracellular Matrix Bioscaffolds; Elsevier Ltd.: Amsterdam, The Netherlands, 2016; ISBN 9781782420958. 
76. Food and Drug Administration. Guideline on Validation of the Limulus ameobocyte Lysate Test as an End-Product Endotoxin Test for Human and Animal Parenteral Drugs, Biological Products, and Medical Devices; U.S. Department of Health \& Human Services: Washington, DC, USA, 1987; pp. 1-30.

77. Stoilov, I.; Starcher, B.C.; Mecham, R.P.; Broekelmann, T.J. Measurement of elastin, collagen, and total protein levels in tissues. In Methods in Cell Biology; Mecham, R.P., Ed.; Elsevier Inc.: Amsterdam, The Netherlands, 2018; Volume 143, pp. 133-146. ISBN 978-0-12-812297-6.

78. Xiong, Y.L. Structure-Function Relationships of Muscle Proteins. In Food Proteins and Their Applications; CRC Press: Boca Raton, FL, USA, 2017; p. 52. ISBN 9780203755617.

79. Gauza-Włodarczyk, M.; Kubisz, L.; Włodarczyk, D. Amino acid composition in determination of collagen origin and assessment of physical factors effects. Int. J. Biol. Macromol. 2017, 104, 987-991. [CrossRef]

80. Nam, K.A.; You, S.G.; Kim, S.M. Molecular and physical characteristics of squid (Todarodes pacificus) skin collagens and biological properties of their enzymatic hydrolysates. J. Food Sci. 2008, 73, 249-255. [CrossRef]

81. Barocas, V.H.; Ph, D.; Hubel, A. Collagen Film-Based Corneal Stroma Equivalent. Tissue Eng. 2006, 12, $1565-1575$.

82. Bardakova, K.N.; Grebenik, E.A.; Istranova, E.V.; Istranov, L.P.; Gerasimov, Y.V.; Grosheva, A.G.; Zharikova, T.M.; Minaev, N.V.; Shavkuta, B.S.; Dudova, D.S.; et al. Reinforced Hybrid Collagen Sponges for Tissue Engineering. Bull. Exp. Biol. Med. 2018, 165, 142-147. [CrossRef]

83. Akram, A.N.; Zhang, C. Extraction of collagen-II with pepsin and ultrasound treatment from chicken sternal cartilage; physicochemical and functional properties. Ultrason. Sonochem. 2020, 64, 105053. [CrossRef] [PubMed]

84. Efremov, Y.M.; Bakhchieva, N.A.; Shavkuta, B.S.; Frolova, A.A.; Kotova, S.L.; Novikov, I.A.; Akovantseva, A.A.; Avetisov, K.S.; Avetisov, S.E.; Timashev, P.S. Mechanical properties of anterior lens capsule assessed with AFM and nanoindenter in relation to human aging, pseudoexfoliation syndrome, and trypan blue staining. J. Mech. Behav. Biomed. Mater. 2020, 112, 104081. [CrossRef] [PubMed]

85. Zorin, V.L.; Pulin, A.A.; Eremin, I.I.; Korsakov, I.N.; Zorina, A.I.; Khromova, N.V.; Sokova, O.I.; Kotenko, K.V.; Kopnin, P.B. Myogenic potential of human alveolar mucosa derived cells Vadim. Cell Cycle 2017, 16, 545-555. [CrossRef] [PubMed]

86. Dominici, M.; Le Blanc, K.; Mueller, I.; Slaper-Cortenbach, I.; Marini, F.C.; Krause, D.S.; Deans, R.J.; Keating, A.; Prockop, D.J.; Horwitz, E.M. Minimal criteria for defining multipotent mesenchymal stromal cells. The International Society for Cellular Therapy position statement. Cytotherapy 2006, 8, 315-317. [CrossRef] [PubMed] 